\title{
CON LOS OJOS PUESTOS EN ESE CONTINENTE CON FORMA DE ARPA: ARQUETIPOS BRASILEÑOS, BÚSQUEDA ESCRITURARIA Y RISTRA DE EXPERIENCIAS EN UN RELATO DEL INTELECTUAL SANTAFESINO ALCIDES GRECA (1889-1956)
}

With eyes on that harp-shaped continent: Brazilian archetypes, writing search, and a bunch of experiences in a narrative of the santafesino intellectual Alcides Greca (1889-1956)

\author{
María F. Antequera* \\ https://orcid.org/0000-0003-4945-7872
}

\section{Resumen}

La presente comunicación explora la intervención cultural del intelectual santafesino Alcides Greca (1889-1956) que tuvo lugar en 1948 por las tierras del Brasil. Proponemos focalizar, principalmente, en la singular perspectiva que Greca inscribe en Bahianos y bandeirantes (1950), a partir de un catálogo de referencias sensibles (Ette, 2004), propio del viajero cultural (Aguilar y Siskind, 2002). Entendemos que este relato resulta un vehículo escriturario singular para traducir nuevas experiencias sociales (Antequera, 2020a) cuyo tópico de interés refulgente es la ciudad. La comunicación consta de tres partes: en la primera, discurrimos en torno a los arquetipos y artefactos urbanos que Greca mensura; en la segunda, analizamos las marcas de escritura autobiográfica que coadyuvan en la búsqueda de una legitimación conjunta de proyecto y sujeto (Antelo, 1998). Por último, examinamos las credenciales que porta Greca en su viaje a Brasil -sus contribuciones en el campo del urbanismo y el derecho municipal-y pasamos revista a los anfitriones que, pródigos en atenciones, lo acompañaron.

$$
<\text { Alcides Greca }><\text { Brasil }><\text { intervención cultural }><\text { arquetipos }>
$$

\begin{abstract}
This article explores the cultural intervention of the santafesino intellectual Alcides Greca (18891956), developed in 1948, in Brazil. Our work focuses mainly on the singular perspective that Greca implemented in Bahianos and bandeirantes (1950) as the starting point of a catalogue of sensitive references (Ette, 2004), typical of a cultural traveler (Aguilar, Siskind 2002). We believe that this narrative represents a scriptural vehicle which interprets new social experiences (Antequera, 2020a), and whose main topic is the city. This article consists of three parts: the first is a discussion on the urban archetypes and artifacts measured by Greca. The second is an analysis of the autobiographical writing traces that contribute to the search of a combined legitimation of project and subject (Antelo 1998). The third, finally, consists of both an exploration of the credential letters carried by Greca in his journey through Brazil -his contributions to urbanism and municipal law-, and a review of the generous hosts that accompanied him.
\end{abstract}

$<$ Alcides Greca $><$ Brazil $><$ cultural intervention $><$ archetypes $>$

Recibido: 11/05/2020//Aceptado: 26/08/2020

\footnotetext{
* Instituto de Estudios Históricos, Económicos, Sociales e Internacionales (IDEHESI). Consejo Nacional de Investigaciones Científicas y Técnicas (CONICET), Argentina. Universidad Católica Argentina. Universidad Nacional de Rosario, mfantequera@hotmail.com
} 
Antequera. Con los ojos puestos en ese continente con forma de arpa: arquetipos brasileños, búsqueda escrituraria...

\section{Introducción}

Un repaso a la investigación argentina nos devela que, en la actualidad, casi no existen publicaciones que se ocupen de la literatura de Alcides Greca, quien nació en 1889 en un poblado del norte de Santa Fe (la localidad de San Javier) y murió en Rosario un lunes 16 de abril de 1956, en una cama del Hospital Italiano Garibaldi. Greca fue un prolífico escritor, pionero cineasta y militante político dentro de las filas del radicalismo ${ }^{1}$. El amplio espectro de sus inquietudes — que incluye el urbanismo, el derecho, la universidad, la literatura, el cine, pero también la suerte de los postergados indígenas mocovíes y de los inmigrantes - ritmaron su trayectoria intelectual. Poco se oye hoy del multifacético Alcides Greca. Sin embargo, en la primera mitad del siglo XX este escritor desplegó una enjundiosa labor intelectual en la esfera pública: en ámbitos como la escritura de jurisprudencia, la docencia e investigación y, también, en lo referido a la escritura ficcional, la labor periodística y la dirección de cine en donde se lo reconoce a ciencia cierta como un pionero. En efecto, El último malón (1917), película que tiene a los relegados mocovíes como protagonistas, es uno de los primeros largometrajes argentinos y uno de los pocos films latinoamericanos recuperados de la década del 10.

La escasa atención que le dedicó la crítica literaria y cultural, decíamos, solo ha intentado ubicar su escritura como emergente en torno a los tipos posibles de narrativa regionalista (Santa Cruz, 1977; Víttori, 1986), o como exponente de un realismo (D’Anna, 2007) que sus novelas Viento norte (1927) o La pampa gringa (1936) exhibirían. Los relatos de viajes reunidos en La torre de los ingleses (1929) y aquellos que analizaremos aquí a partir de Bahianos y bandeirantes (1950) —así como un conjunto disperso de artículos periodísticos, y una obra inédita de 1955 titulada Significación de Juan Álvarez en la cultura de Rosario - traducen experiencias traslaticias concretas, realizadas por América Latina desde la temprana juventud hasta la madurez (Antequera, 2011; 2018).

Ahora bien, entre el primer libro de viajes de Greca titulado La torre de los ingleses (1929) y Bahianos y bandeirantes, media una distancia de veinte años. Ambos textos contribuyen a manifestar una nueva subjetividad al concebir el relato de viajes como exaltación de sensaciones, es decir, como un nuevo archivo de experiencias (cfr. Monteleone, 1998), estableciendo una línea de continuidad en su producción escrituraria. Sin embargo, las motivaciones y los anhelos, los sitios visitados y las expectativas de ambos recorridos son diversos. En La torre..., la conjunción entre estudio, turismo y búsqueda de diversión fueron los motivos que Greca priorizó y que lo arrancaron de Rosario para su experiencia diletante por Argentina, Chile, Bolivia y Perú (Antequera, 2020a). Mientras que en Bahianos..., en cambio, la razón prioritaria del viaje fue dictar conferencias frente a un público de universitarios y profesionales ${ }^{2}$. Con un marcado cariz

\footnotetext{
1 Figura pública, polemista, representante parlamentario, recordemos que fue diputado provincial por el departamento San Javier desde 1912 hasta 1916. En 1920 asumió como senador y también como constituyente para la reforma de la Constitución Provincial. Fue diputado nacional en 1926, reelecto en 1930, cumpliendo esta función hasta el derrocamiento de Hipólito Yrigoyen por el golpe militar del general Uriburu. Agradecemos estos datos a la Lic. Verónica Greca, bisnieta del escritor.

2 Analizar el tema prometido en el título mismo de esta comunicación, implica el ejercicio de volver hacia un trabajo previo, tanto por las síntesis que, parcialmente, aquí se retoman con miras a desarrollar
} 
académico-profesional, viajó hacia tierras brasileñas como representante de la Universidad Nacional del Litoral, casa de estudios donde ejercía la docencia en la carrera de Abogacía, en las cátedras de Derecho Municipal Comparado y Derecho Administrativo.

A diferencia de sus viajes de juventud, que nos remiten a un intelectual con muchas ansias por conocer sitios recónditos de la geografía latinoamericana, en sus viajes de madurez en la década del cincuenta se concentra solo en algunas ciudades de "ese continente con forma de arpa" (Greca, 1950a, p. 4) que es Brasil. Nos referimos a San Pablo, Bahía y Río de Janeiro, junto a breves estadías en Campinas, Santos y Araçatuba. Podríamos decir que estas andariegas experiencias, de alguna manera, fueron la resultante de un compromiso profesional asumido, y no de un gusto propio ligado al ocio o al turismo. Sin embargo, resulta interesante destacar la franca puesta en espejo de, fundamentalmente, dos ciudades brasileñas: Bahía y San Pablo.

Ahora bien, como corolario de este periplo por tierras brasileñas, Greca escribió no uno sino dos libros: en rigor, tanto Bahianos... - texto a caballo entre la búsqueda de arquetipos y las descripciones propias de los relatos de viajes- como Una nueva capital para la Nación Argentina (1950b) funcionan como testimonio documental de esta experiencia traslaticia. Por una parte, Greca intenta definir arquetípicamente a los bahianos y a los paulistas, describe aquello que ve y construye un relato basado en la recopilación de impresiones y visiones acopiadas en el viaje. Por otra parte, caracteriza y plantea los problemas que aquejan a la Argentina para esgrimir soluciones que, experiencia brasileña mediante, considera pertinentes y científicas. En otros términos, podríamos argüir que Bahianos ... narra el viaje y sus impresiones y Una nueva capital... recoge parte de los conceptos vertidos en las conferencias que dictó y aquello que pudo aprehender de las discusiones sostenidas con otros académicos. Aunque desde diversos registros escriturarios, entre ambos textos no habría rupturas ni hiatos sino, al contrario, encadenamiento, ya que uno sería apenas la continuidad del otro.

En esta comunicación, al concentrarnos en el texto sobre el periplo en tierras brasileñas, bregamos por desentrañar esa ristra de experiencias y vivencias del viajero, donde ocupa un lugar prevalente su vinculación con intelectuales de fuste ya que, en rigor, como decíamos más arriba, viaja en carácter de representante de una universidad que, por cierto, contribuyó a forjar desde sus orígenes. No fue invitado como literato ni como cineasta, ni tampoco como militante político - aunque todo eso lo fuera cabalmente- sino en calidad de académico especialista en urbanismo y derecho municipal. El contexto, ciertamente particular, de la invitación, le imprime un carácter específico pues se estaba discutiendo el traslado de la capital brasileña y la erección de Brasilia, que será fundada unos pocos años después (1961). Greca aprovechará para discutir con sus pares del vecino país y, a la vuelta, escribirá estos dos textos influido por estos debates intelectuales. Las personalidades con las que se relaciona se vinculan

algunos aspectos no descriptos en la comunicación previa. En efecto, una muy preliminar aproximación a este tema fue leída en las VI Jornada de discusión de avances de Investigación en Historia Argentina: fuentes, problemas y métodos. Ver Actas IH IDEHESI CONICET y Facultad de Derecho y Ciencias Sociales del Rosario, UCA, Rosario, 2016. 
Antequera. Con los ojos puestos en ese continente con forma de arpa: arquetipos brasileños, búsqueda escrituraria...

directamente a las órbitas del urbanismo y de las leyes, ámbitos propios de su labor académico-profesional.

Nos interesa explorar, entonces, la intervención cultural propiciada por esa experiencia viajera de 1948. Para este fin, proponemos focalizar en la singular perspectiva que el escritor viajero inscribe en Bahianos, a partir de un catálogo de referencias sensibles (Ette, 2004), propio de los relatos de viajes, que se fundamentan en la descripción de arquetipos y artefactos urbanos. Mediante un diálogo con materiales de diversa raigambre, entendemos que este relato resulta el vehículo escriturario pertinente para traducir nuevas experiencias sociales cuyo tópico de interés refulgente es la ciudad. La comunicación consta de tres partes. En la primera, discurrimos en torno a los arquetipos y artefactos urbanos que Greca compara y mensura. En la segunda, analizamos aquellas marcas autobiográficas que van conformando la escritura del relato de viajes y que dan lugar a la construcción del sujeto escritural de doble experiencia: experiencia de viaje y de escritura. Por último, examinamos las credenciales que porta Greca en su viaje a Brasil como sus contribuciones en el campo del urbanismo y el derecho municipal. Para esto último relevamos algunas notas reunidas en Una nueva capital - frente a los problemas que enfrentaban Brasil y Argentina- y, para finalizar, nos detenemos en describir a los anfitriones que, pródigos en atenciones, lo acompañaron en su travesía.

\section{Arquetipos y artefactos urbanos: el cotejo entre Bahía y San Pablo}

Para comenzar, describamos algunas características de Bahianos y bandeirantes. El volumen presenta como subtítulo: "Ensayos sobre los hombres arquetipos del Brasil actual" que da cuenta anticipada del cariz del mismo. El relato describe un desplazamiento que se desarrolló durante los meses de noviembre y diciembre de 1948: estas jornadas fueron la ocasión propicia para atesorar experiencias en tierras del Brasil en lo concerniente a sus artefactos urbanos, sus habitantes y sus costumbres. La obra se editó a modo de una separata de la revista Universidad de la Universidad Nacional del Litoral, en 1950. En 1955, el texto se tradujo al portugués y fue publicado por la Municipalidad de Salvador de Bahía. Ninguna de las dos versiones fue reeditada hasta la fecha.

Las ciudades descriptas son fundamentalmente San Salvador de Bahía y San Pablo, aunque también es de la partida Río de Janeiro, la cual deja en Greca una impronta imborrable, una herida en su imaginación territorial (Antequera, 2007). Sin embargo, además de referir los diversos sitios recorridos, en un continuum textual sin capítulos ni subtítulos, Greca se propone establecer semblanzas - especulares y antitéticas, descriptivas y generalizadoras - de los bahianos y los paulistas. De hecho, su mirada escrutadora pretende penetrar en la "psicología de los bahianos y los paulistas" (Greca, 1950 a, p. 2) y realizar un paralelo entre los mismos: estos son sus objetivos declarados. Por un breve lapso de tiempo, es decir, de paso, también ambuló por la ciudad-puerto de Santos: desde allí tomó el navío que lo condujo a Río. Del mismo modo, visitó Araçatuba, una localidad del oeste paulista, cercana a los márgenes del Paraná, y conoció asimismo la pujante Campinas, ciudad industrial situada en una rica zona agropecuaria, 
dentro del estado de San Pablo. Cabe destacar que Greca contaba con 59 años y viajaba acompañado por su esposa, Rosa Pierri (Roxana) (Figura 1).

Figura 1. Alcides Greca junto a su esposa Rosa Pierri e Ives de Oliveira

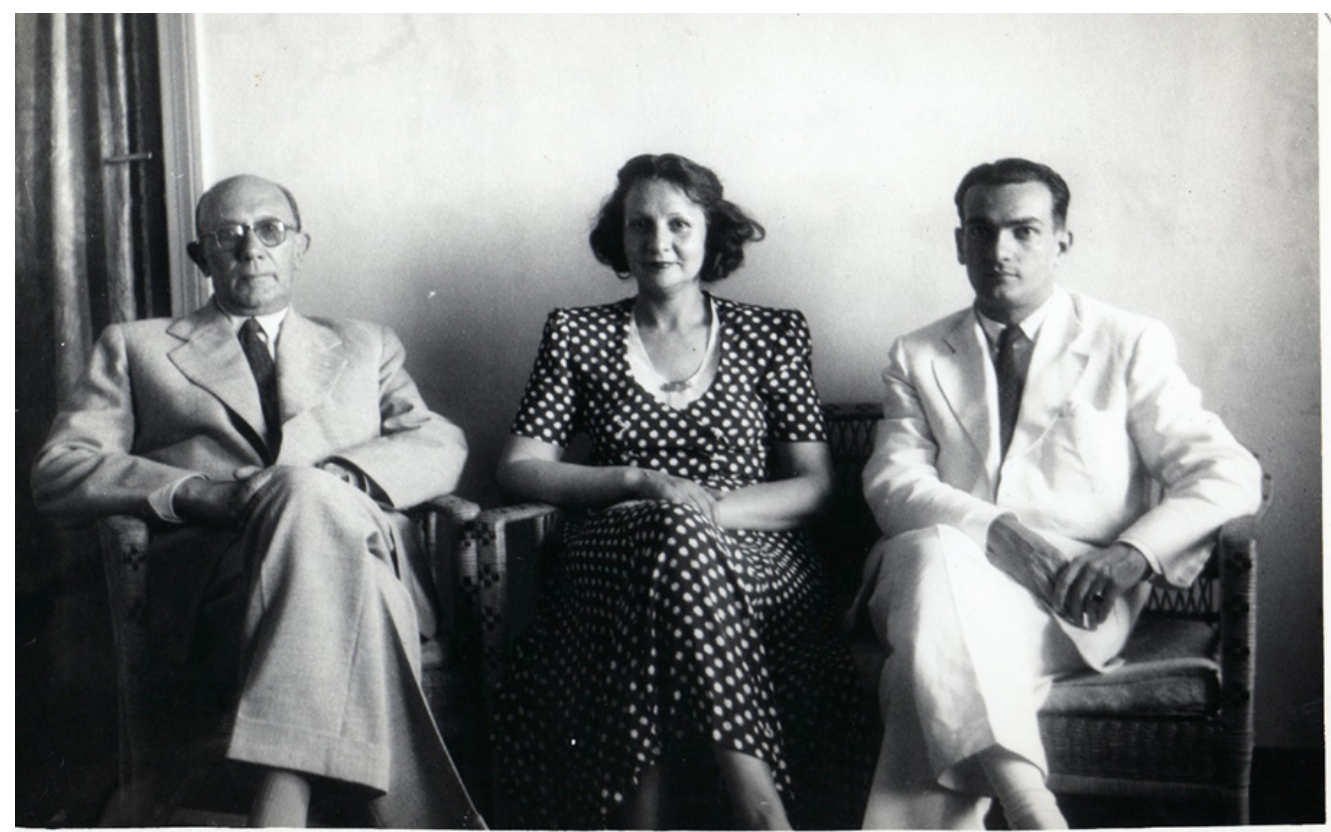

Fuente: gentileza Familia Greca (Fondo documental Alcides Greca).

Como ya anticipáramos, Greca practicó el género relato de viajes también en la década del veinte: La torre fue su primera incursión. Bahianos, por su parte, fue escrito veinte años después. Este hiato temporal entre una y otra publicación multiplica una diferencia motivacional del viaje y del relato del mismo: en su primera experiencia traslaticia Greca recorre fundamentalmente Chile, Bolivia, Perú y Argentina por el mero placer de descubrir nuevas sensaciones, aguijoneado por la curiosidad y el deseo. En cambio, en la segunda obra referida, cuyo itinerario también será latinoamericano pero específicamente por ciudades brasileñas, revestirá el carácter de viaje de trabajo donde, motivado por obligaciones institucionales, se las ingeniará para conocer y mensurar los espacios visitados. A la vuelta, relatará sus vivencias en Bahianos... y compendiará el núcleo de sus conferencias junto al saber consolidado en Brasil en Una nueva capital para la República Argentina.

Podríamos sostener, no obstante, que estas experiencias relatadas son para Greca la tipificación de un viaje ya conocido: no es la primera vez que asiste en representación de la UNL a una reunión científica o profesional, en otro país latinoamericano. En noviembre de 1938, por ejemplo, había visitado La Habana como delegado del Primer Congreso Panamericano de Municipios ${ }^{3}$. Sin embargo, sí es la primera vez que despliega,

\footnotetext{
3 Convocado por el gobierno cubano, tuvo lugar en la isla este Congreso entre el 14 y el 19 de noviembre
} 
Antequera. Con los ojos puestos en ese continente con forma de arpa: arquetipos brasileños, búsqueda escrituraria...

en clave de relato de viajes, ese desplazamiento por trabajo. Greca, convertido en viajero cultural (Aguilar y Siskind, 2002) en el Brasil, en virtud de encarnar el rol de experto e intelectual (Plotkin y Neiburg, 2004) parece revivir, si bien en otra clave, la necesidad de incidir mediante envalentonadas conferencias y disertaciones (Figuras 2 y 3). Las fotografías que acompañan este escrito dan cuenta del cariz de las variopintas reuniones, los coloquios y los distendidos encuentros con personalidades de la intelectualidad paulista, jalonando así las intensas semanas en Brasil.

Como contraste entre retratos a primera vista entre figuras ejemplares, pensadas al modo de arquetipos del Brasil de la década del 50, funcionan los postulados de Bahianos. La confrontación supera por elución el par centralismo/periferia o ciudad capital e interior y la forja de generalizaciones que, sin empacho, extiende al conjunto de los habitantes de dichas localidades atraviesa todo el volumen: "Vacilamos un tanto al poner título a este paralelo que vamos a intentar sobre dos tipos de hombres del Brasil actual, cuyas modalidades e idiosincrasia pretendemos haber sorprendido en una reciente visita a nuestros vecinos" (Greca, 1950a, p. 3). De alguna manera, establecer semblanzas sobre una sinécdoque de Brasil (San Pablo y Bahía) y amplificar esta mirada hacia todo el país, es decir, hacer de una cartografía regional un sinónimo de lo brasileño, implica un gesto metonímico y simplificador que en última instancia nos viene a decir que estos espacios condensarían (y superarían) a la nación (Demaría, 2014). Según su mirada contrapuntística, si los bahianos custodian tradiciones, los paulistas construyen futuro:

Si tuviésemos que elegir lo más típicamente brasileño, tendríamos que buscarlo en los paulistas y bahianos. El bahiano es el hombre del viejo Brasil, que se enorgullece de sus tradiciones, permitiéndose, no obstante, hacer finas ironías acerca de ellas en conversaciones, crónicas y libros. El paulista no gasta ironías, ni posturas académicas; no hace alarde de sonrisas volterianas. Es un realizador, un constructor, que no tiene tiempo siquiera para gozar de su propia obra (Greca, 1950a, p. 26).

cuya temática giraba en torno a profundizar vinculaciones entre los municipios latinoamericanos. Acérrimo defensor de la autonomía municipal, Greca expuso en este encuentro académico, un trabajo titulado "Elección, organización y atribuciones del poder ejecutivo municipal en los países de América", dentro del eje temático Organización municipal, según recopila el investigador venezolano J. J. Frechilla (2002). Dicha ponencia suscitó la aprobación unánime en lo concerniente a la creación de organismos superiores de coordinación y contralor intermunicipal que regulen el buen funcionamiento de los servicios de sanidad, policía, servicios públicos, entre otros (Cfr. Greca 1939, p. 6). En esta ocasión viajó junto al también abogado santafesino Salvador Dana Montaño (1906-1992). 
Figura 2. Alcides Greca en plena disertación en la Ordem dos Advogados do Brasil.

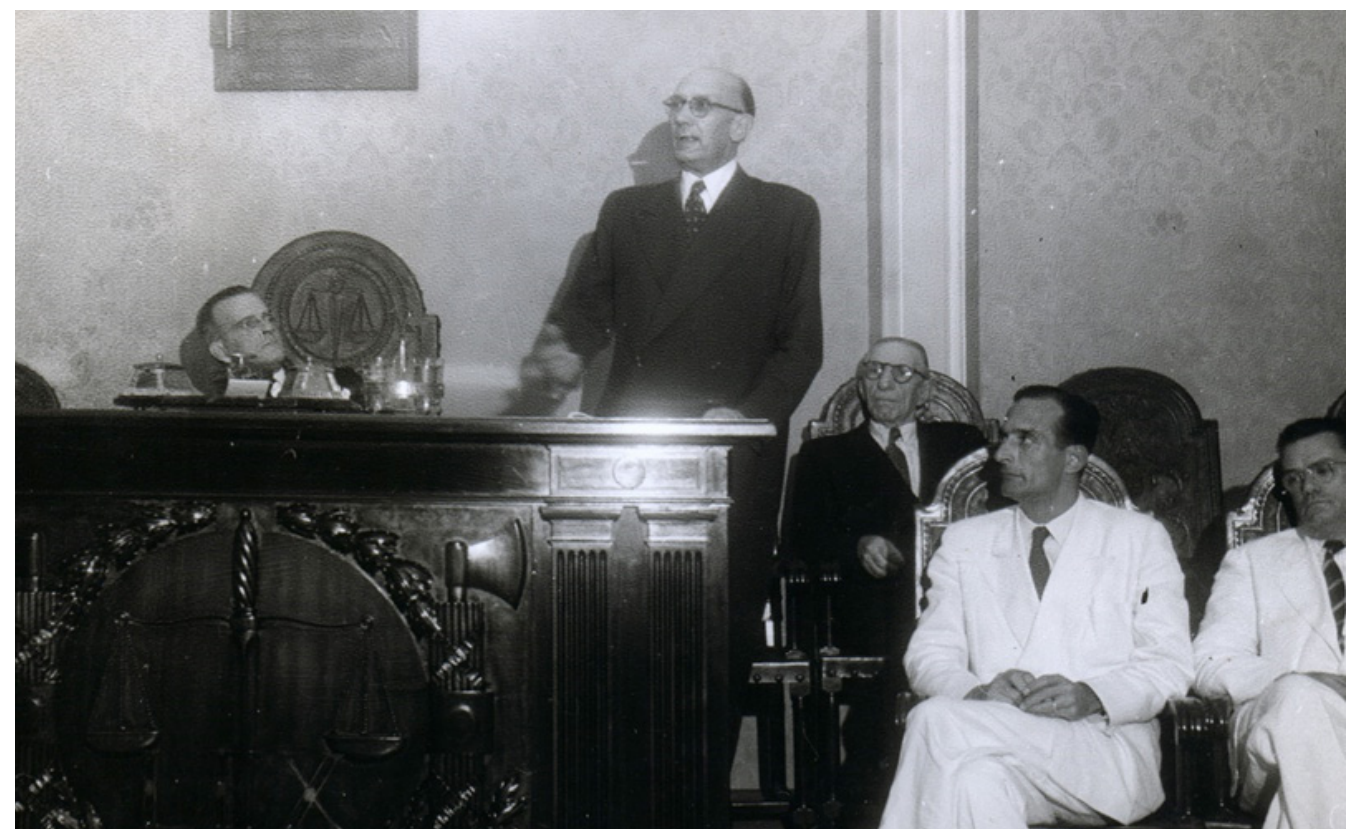

Fuente: gentileza Familia Greca (Fondo documental Alcides Greca).

Figura 3. Mesa que presidió en la primera conferencia de la Ordem dos Advogados do Brasil (Bahía)

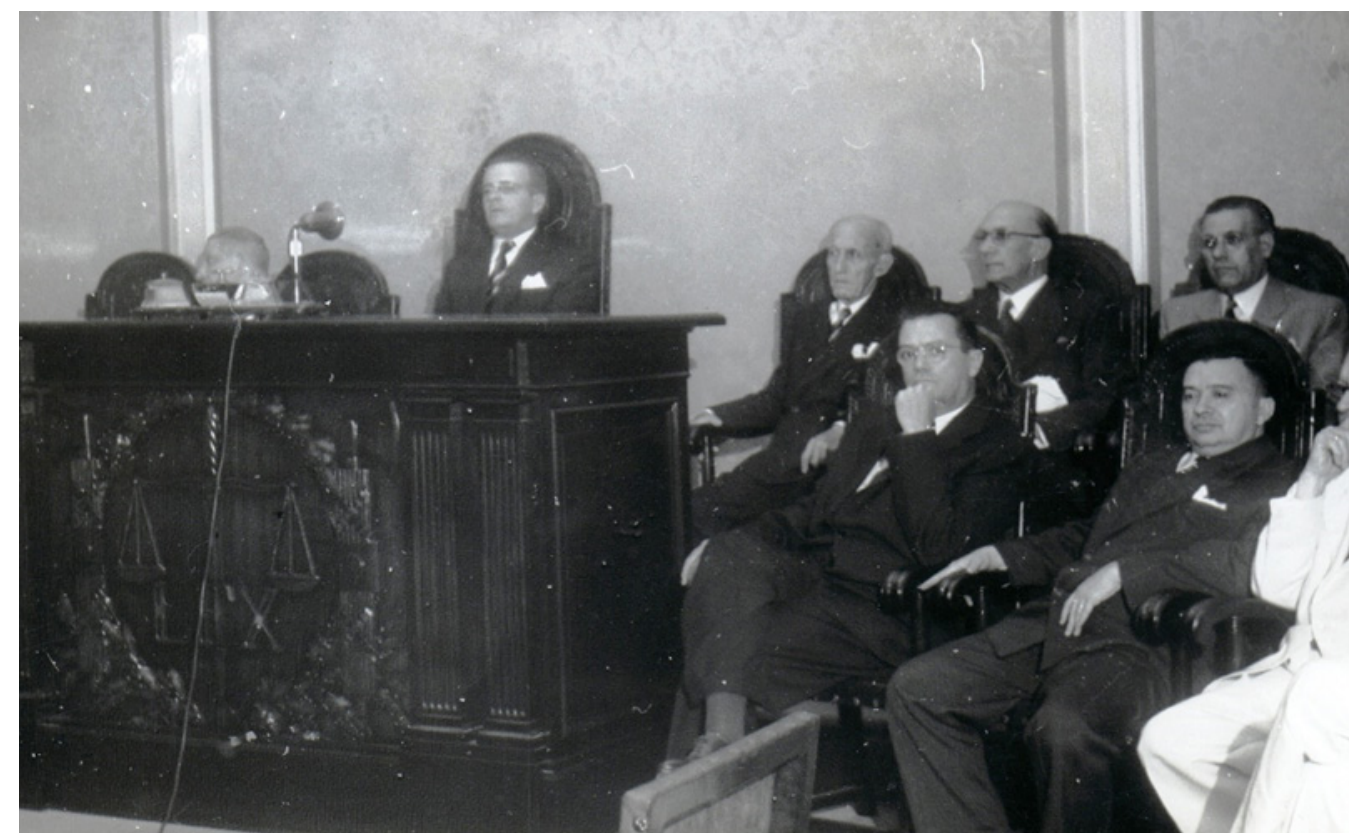

Fuente: Fondo documental Alcides Greca. 
Antequera. Con los ojos puestos en ese continente con forma de arpa: arquetipos brasileños, búsqueda escrituraria...

Ahora bien, considerando que el género relato de viajes apela habitualmente a la utilización de la comparación como recurso articulador, podríamos destacar que en aquellos fragmentos en donde Greca intenta establecer contrastes - ya sea entre habitantes o diferentes artefactos urbanos - una herramienta utilizada es, claro está, la descripción. Estrechamente ligada a la construcción del efecto de lo real barthesiano, entendemos que hunde sus raíces en la pretensión de mímesis de este género. Las descripciones y caracterizaciones de los habitantes de "la ciudad del pausado vivir" (Greca, 1950a, p. 14) abundan:

"El tiempo ha detenido su marcha en la Bahía de Todos los Santos. Para el bahiano el reloj es, cuando más, un adminículo que solo será observado para llegar exactamente a una cita, porque ello forma parte de su proverbial cortesía. Pese a las numerosas torres de sus iglesias, no hay casi relojes públicos en Bahía. Los relojes solo se necesitan donde existen horarios y hombres-horarios, especímenes desconocidos en aquella noble ciudad" (Greca, 1950a, p. 6).

En cambio:

“El paulista parece nervioso, se expide rápidamente, consulta el reloj, apremiado por mil cosas, torturado por graves problemas. Se despide a los cinco minutos. El bahiano se entrega al primer apretón de manos. El paulista, como hombre de lucha y de garra, desconfía. Pero tiene mucha razón. Actúa en una ciudad agitada y cosmopolita, entre gentes extrañas, venidas de todas partes. Se parece, en ello, al argentino de nuestros puertos del Litoral" (Greca, 1950a, p. 6).

El paulista, para Greca, se parece más a los habitantes que él conoce en las ciudadespuerto del Litoral argentino: apurado, desconfiado y a la defensiva por estar inmerso en un contexto competitivo. El bahiano, en contraste, nunca tiene prisas. Aventureros de suyo, los paulistas ${ }^{4}$, cuya potencia constructiva se concentra también en la arquitectura y el urbanismo, ensancharon las fronteras de Brasil a base de conquistar territorios y fundar ciudades; antes cultivaban, ahora emplean sus energías en industrias y levantan fábricas y rascacielos (Greca, 1950a, p. 3). Así explicita el autor las ansias paulistas de conquista y aventura materializadas en las edificaciones (Greca, 1950a, pp. 3-7):

En los paulistas no se ha interrumpido el impulso inicial; solo ha cambiado de rumbo. Siguen siendo los mismos aventureros.

\footnotetext{
${ }^{4}$ Dice Greca (1950a, p. 7): "El espíritu bandeirante de San Pablo en ninguna parte está mejor simbolizado que en si escudo municipal. Sobre fondo rojo, el brazo de hierro de un guerrero esgrime una pica, y lleva debajo esta leyenda: 'Non ducor. Duco'. No soy conducido, conduzco. Bello y orgulloso lema que significa que los paulistas se habían adelantado en siglos a esos profesores de energía que se llamaban Nietzche y Marinetti, precursores de los Hitler y Mussollini. Pero el lema bandeirante tiene un sentido más idealista y humano que el "vive peligrosamente' del credo fascista".
} 
Fueron los bandeirantes y mamelucos de San Pablo quienes ensancharon las fronteras del Brasil [...] abrieron caminos, fundaron ciudades y se dedicaron a cultivar los campos [...] Ahora emplean sus energías en empresas industriales. Levantan fábricas y rascacielos. El impulso ha tomado un sentido vertical, disputándole espacio a las estrellas. Los paulistas deben tener sus ascendientes en los constructores de la torre de Babel. Si no se los detiene serán los primeros excursionistas que llegarán a la Luna.

De este modo, Greca define el espíritu paulista, emprendedor e inquieto, cuyo ritmo acelerado representa el futuro de la nación. Nos dice también: "Para el paulista la palabra 'imposible' no existe en el diccionario". Y ejemplifica: "Un rascacielo (sic) de la ciudad, de veinticuatro pisos, apenas construido, se inclinó setenta centímetros sobre un costado, descubriéndose entonces que una parte de San Pablo está edificada sobre el lecho movedizo de un antiguo lago. Nadie quería habitar, por cierto, esta nueva torre de Pisa [...] La empresa constructora, velando por su prestigio, lo enderezó desde su base, gastando más millones de los que le habría costado el reconstruirlo de nuevo" (Greca, 1950a, p. 7)".

Sin embargo, ser bahiano implica otras características: "significa en Brasil ser algo muy particular, dada su especial idiosincrasia, la simpatía que irradia, su vivacidad mental y el sentido llano y amable que tiene de la vida" (Greca, 1950a, p. 5). No hay premuras ni nerviosismos para los habitantes de esta región nordestina, tampoco ritmos acelerados como sí ve en los paulistas: los bahianos son afables, amables y locuaces, gustan de la buena vida, de la buena mesa, de las plácidas tertulias, del ambiente de los libros. Conservan celosamente los tesoros artísticos de la ciudad y se enorgullecen ante el prestigio de sus tradiciones. Asimismo, Greca describe: "El bahiano es el brasileño típico, el hombre del viejo Brasil, que ha absorbido la esencia de una milenaria cultura trasplantada en todo su esplendor desde la gloriosa Lusitania. El bahiano representa el pasado; el paulista, el futuro" (p. 8). Sin embargo, tanto el bahiano como el paulista no dejan de ser brasileños — nos dice Greca— por la afectividad, la gentileza y el deseo de agradar siempre. Pero cada uno, a su manera.

\section{La autobiografía de un ácrata de las letras}

En un breve escrito anterior a Bahianos, Greca delinea una suerte de autobiografía hecha por encargo. Nos referimos a Conato de autobiografia (1941), el cual salió a la

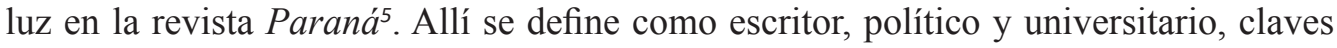
centrales de su polifacético itinerario intelectual:

5 El director de la publicación era Ricardo Ernesto Montes I Bradley y entre quienes colaboraban, podemos citar a los escritores Amaro Villanueva, Juan L. Ortiz, Luis Gudiño Kramer, Juan Filloy, Fausto Hernández, Carlos Carlino, Rosa Wernicke, Marcelino Román y los artistas plásticos Julio Vanzo, Leónidas Gambartes, Juan Grela G., Ricardo Warecki, Pedro Laborde, César Caggiano y Hermenegildo Gianzone, entre otros. 
Si en alguna forma se desea 'tantear' hasta qué punto llega la vanidad de un hombre, no hay mejor medio que el pedirle que escriba su autobiografía. Pero...como en el gremio todos nos conocemos, a mí no me pescan en el 'Paraná'. ¡Hace rato dejé de ser moncholo!

No alardeo de modesto, pero tampoco soy vanidoso. No creo en la gloria ni en la fama. La única fama auténtica, efectiva, es la mala fama. Pero esta la elaboran nuestros prójimos, generalmente, nuestros más 'queridos amigos'. Ello me exime, por consiguiente, de la ingrata tarea de desacreditarme.

De mi vida solo podré mencionar dos hechos reales, valederos. Uno de ellos es el de mi nacimiento, que ocurrió un 13 de febrero en el pueblo de San Javier. (Alimento la ingenua ilusión de que esta noticia servirá para que en mi próximo cumpleaños sea obsequiado con obras de arte, artículos de bazar, bebestibles y confituras). En cuanto al año, no están muy de acuerdo las personas que me conocen. Hay quienes dicen que fue en el 1900; otras, mejor informadas que en el 1910. No faltan malvados que aseguran que nací un poco antes del 90. El otro acontecimiento que, por cierto, será motivo de gran satisfacción para muchos de mis conocidos, correligionarios, parientes y amigos, es el de mi muerte, que podrá ocurrir cualquier día de estos. (Viajo en ómnibus a Santa Fe todas las semanas. Almuerzo con frecuencia en la casa-quinta de Guillermo Ruíz Díaz).

Entre estas dos fechas, hay un sinnúmero de sucesos, tentativas $y$ anhelos. Pero todo ello es solo una gran humareda. ¡Humo de pajonal isleño!

En mi vida de político y universitario he ocupado muchos cargos, pero, hasta el momento, no he sido presidente de la República, empleo al que siempre he creído que podía aspirar, desde que han llegado a él más de cuatro, 'mucho más burros que yo'. Pero... no se alarme la gente. He decidido -ipor ahora!- no ser presidente de la República.

Como escritor, hasta la fecha, no he sido premiado ni banqueteado. Creo que he escrito diez y siete libros. Otros malvados me atribuyen diez y nueve. (Me cuelgan dos que escribió un homónimo, pariente mío allá por el año 1910, cuando yo recién había nacido).

¿La causa de mi vocación literaria? Como de noche me desvelo, trato de vengarme de los que duermen apaciblemente. Escribo libros. (En este sentido, me considero un ácrata de las letras). Alimento, con ello, el justiciero propósito de hacer 
sentir a mis prójimos la angustia de las largas vigilias que yo sufro. Pero, según las noticias que tengo, el resultado ha sido completamente adverso. Mis libros son usados como anestésicos (Greca, 1941, pp. 249-250).

De algún modo, al reírse de sí mismo, deja entrever que quiere ser recordado por sus obras literarias, escritas al calor de sus insomnios. Se define, como también sucede en tantos otros de sus escritos y en algunas entrevistas, con vocación literaria: su máxima aspiración es ser recordado como un hombre de letras (Antequera, 2020a, 2020b). Destellos de imágenes de escritor, en plural, se van delineando en sus textos. El entramado narrador-protagonista textual-autor construye un nudo teórico problemático en su literatura. En efecto, protagonista textual, personaje, autor real, narrador resultan, como sabemos, categorías de diverso orden pero entrecruzadas en los relatos de viajes (Antequera, 2019a) y en Bahianos, en particular. Horadando la porosidad de sus fronteras, estas categorías entreveradas proponen un juego de confusiones a través de un yo condensado cuya garantía de lo relatado (o credibilidad) está centrada en la rúbrica. En las entrañas del relato de viajes, género híbrido y fronterizo, a horcajadas entre la literatura y la historia, se produce la intersección de lugares, saberes y epifanías - o bien, espaciamiento, experimentación y descubrimiento (Rosa, 2006, p. 21) - que son las formas nucleares de los viajes (Antequera, 2017).

Como subrayan algunos críticos, los viajes detentan un carácter preformado: son un relato antes de que hubiera relato, pues contienen en su propia disposición, la estructura de una narración, básicamente un comienzo (la partida) que interrumpe el continuum de la vida y un fin (el regreso), generando cambios de situaciones y desarrollo de acciones. En términos generales, podríamos apuntar que los relatos de viaje de Greca, en su conjunto, tienen un fuerte carácter autobiográfico si pensamos que, desde el comienzo, el intelectual está presente en sus páginas con comentarios sobre su personalidad y sus gustos, sus experiencias y sus posicionamientos ideológicos, hilvanando la relación con otros escritores y artistas, relatando detalles que se pueden constatar en su itinerario biográfico. En este sentido, consideramos que analizar algunos elementos autobiográficos permite avanzar en el conocimiento del conjunto de la obra intelectual de Greca.

Los escritores construyen con gran frecuencia en sus textos figuras de escritor, imágenes proyectivas, fluidas, contra o anti imágenes en lo relativo a lo que la literatura es y en cuanto a su idea de escritor (Gramuglio, 1992): su lugar en la historia, su relación con sus pares, su filiación literaria, su clase social, su relación con el poder, etc. Greca no se sustrae a este influjo. Al recrear un itinerario emprendido unos meses antes, cincela una autobiografía acotada a los meses transcurridos en el vecino país con la pretensión de ser fiel a lo relatado. En este sentido, apela a diversas estrategias discursivas que cimientan la verosimilitud: también son las descripciones y las comparaciones las herramientas que coadyuvan a tal fin. Por eso, referencias a sus sensaciones, detalles familiares, experiencias, entre otros, proliferan en clave autobiográfica mediante el uso de la primera persona del singular. La construcción de sujeto escritural se vale, en 
Antequera. Con los ojos puestos en ese continente con forma de arpa: arquetipos brasileños, búsqueda escrituraria...

función de lo dicho, de los detalles más nimios y/o personales, como ciertos detalles relativos al clima de los lugares visitados que sirven para poner en funcionamiento una operación contrastiva con el lugar de origen, propia del relato de viajes:

Una de las grandes sorpresas que me ha deparado el Brasil ha sido la benignidad de su clima. Solemos soportar en Santa Fe días agobiantes de calor húmedo con más de cuarenta grados a la sombra. Las isotermas y los meteorólogos nos habían enseñado que se debe calcular el aumento de un grado por cada cien kilómetros que se avanza en dirección al norte. Midiendo distancias, pensé, con bastante zozobra, que cuando llegara a Bahía la temperatura se habría elevado un poco más arriba de los cien grados de la ebullición. ¿Me resignaría a regresar a la Argentina en la forma de momia egipcia o de fruta desecada? ¡Soberbio chasco! Nuestro viaje se llevó a cabo en el mes de noviembre y primeros días de diciembre. No sé si fue suerte o casualidad, pero debo decir que en ningún momento experimenté esas temperaturas agobiantes de Buenos Aires, Rosario o Santa Fe. Mientras que en todo el norte de la Argentina, en verano la gente se recluye en sus casas a la hora de la siesta y los negocios se cierran de doce a cuatro de la tarde, en Bahía, ya cerca del Ecuador, la población circula animadamente por las calles. La única vez que experimenté verdadero calor [...] fue al regreso, cuando el navío entró en las aguas del Río de la Plata (Greca, 1950a, pp.15-16).

En este expresivo fragmento Greca nos cuenta que la fecha precisa en que el viaje se efectuó, como también se puede constatar en las fotografías que forman parte del acervo documental con el que venimos trabajando desde 2007. Asimismo, Greca relata que el medio de locomoción utilizado desde Argentina fue el barco. Se trasluce, también, el dato autobiográfico al confrontar el benigno clima de Brasil y el que tenía que sufrir en la calurosa y húmeda ciudad de Santa Fe: él vivía en Rosario, pero desarrollaba parte de su actividad docente en la ciudad capital. La vara desde la que mide aquello que ve es la ciudad-puerto en que reside.

De esta manera, se constata que el procedimiento fundante del relato de viajes radica en la constitución de un sujeto de enunciación de doble experiencia: experiencia de viaje y de escritura. Podríamos pensar, entonces, que la escritura autobiográfica marca la trayectoria que busca una legitimación conjunta de proyecto y sujeto (Antelo, 1998, p. 19) en Greca. En rigor, es un personaje en tránsito cuyo andar atraviesa esta instancia dual: un sujeto que realiza un desplazamiento geográfico-cultural concreto, pero que, además, escribe a posteriori esa experiencia mediatizada por el género relato de viajes. En ese linde de imprecisión y búsqueda escrituraria, entre lo sucedido y lo contado, se fragua el desafío del escritor viajero, cuyo estatuto - entre lo ficcional, lo autobiográfico y lo 
documental - como vemos, es peculiar. El viaje de la escritura y la escritura del viaje se revelan como dos actividades inextricablemente relacionadas entre sí.

Ir a Brasil resulta fundamental, a la sazón, para la exploración del espacio y de su propia subjetividad y para dirimir esa dialéctica entre lo propio y lo ajeno, por cierto, tan cara también a los relatos de viajes: el contraste que genera la travesía diletante implica un darse cuenta en el sujeto viajero de lo que se es y de lo que no se es. Sin embargo, también presupone una definición del sujeto que clasifica, describe $\mathrm{y}$, de este modo, interpreta aquello que ve. Más que comprobación fáctica de un saber ya acopiado, el viaje a tierras brasileñas es para Greca puro descubrimiento: en primer lugar, como todo viajero que se precie de tal, de sí mismo. Al utilizar la primera persona (en el comienzo del plural, para luego sí dar lugar al singular) como marca textual se refrenda esa pretensión autobiográfica en el relato, también al narrar aficiones y "anécdotas", o bien al afirmar que lo que se cuenta es "lo que realmente sucedió", procedimiento ciertamente muy presente en esta tipología textual. Sin embargo, resulta insoslayable apuntar aquí que, como al pasar, sostiene que tamaña pretensión -la de aprehender cabalmente las características de los hombres tipo- termina en un rutilante fracaso (pp. 4-9).

Ávido por conocer otros sitios es, en primer término, un viajero inquieto y un cronista que da rienda suelta a su curiosidad: podríamos definirlo también como un escudriñador de ciudades. Precisamente, existe un tipo de imaginación territorial o socioespacial que configura semánticamente el viaje: el entramado de un paisaje no es la simple configuración geográfica del terreno, sino que se construye a partir de la mirada del viajero que le otorga una impronta y lo resignifica. Sin embargo, contar un viaje, relatarlo, para Greca, no es solamente hacer descripciones sino traducir fielmente impresiones personales que van roturando el texto. El viajero imagina territorialmente al referir $\mathrm{y}$, a fin de cuentas, empuña una autobiografía acotada al lapso temporal del periplo. Por estas razones, el relato de viajes se constituye en una potente máquina de lectura (Demaría, 2014, p. 235) que sufraga la expansión del capital simbólico del viajero-escritor.

Ahora bien, la ristra de reliquias autobiográficas (Aurell, 2004) se engarza a otra cuestión digna de mencionar: estos relatos detentan una pretensión documental, como forma de escritura que reposa en la memoria (la productividad de la memoria se conjuga en el relato), entre lo que se recuerda y lo que se olvida, mediando una distancia temporal entre el tiempo de la vivencia (presente del relato, pasado de lo narrado) y el tiempo de la escritura (Cfr. Sarlo, 2004). No es de extrañar, entonces, que la actividad escrituraria fuera para Greca una actividad postrera - no hay contemporaneidad entre vivencia y escritura-, ligada al sosiego de su escritorio, a la decantación de las imágenes captadas en pleno movimiento, es decir, una actividad ligada a la remembranza.

\section{Una postal de Río de Janeiro}

Ese carácter autobiográfico de los textos se inscribe utilizando la primera persona, como decíamos, bregando por subrayar la autenticidad del relato. El entramado que constituyen el narrador, el autor y el personaje rubrica esa vocación o pretensión 
Antequera. Con los ojos puestos en ese continente con forma de arpa: arquetipos brasileños, búsqueda escrituraria...

documental. El fragmento en donde Greca hace alusión a Río de Janeiro es uno de los pasajes del libro en donde se presenta con mayor fuerza este carácter autobiográfico. Esta ciudad deja huella en la sensibilidad estética y cromática del intelectual: "Mi visión de Río es caótica: tiene algo de lo que se ve en sueños o en los delirios de la fiebre. Veo cerros, florestas, brazos de mar, islas, palacios, rascacielos, favelas, calles y barrios en distintos planos, cual si fuese la alocada acuarela de un pintor futurista" (Greca, 1950a, p. 22). Las enumeraciones intercalan elementos de la naturaleza -florestas, cerros, mar, islas- y los productos del hombre: palacios, rascacielos, calles y barrios así como las favelas o villas miseria, ese producto de la modernización y a la vez - y he aquí la paradoja- la condena de su negación, su antítesis.

En rigor, Río de Janeiro, ciudad que ha sido ya descripta y fotografiada en sus monumentos y atracciones turísticas por tantos artistas, se le presenta a Greca como un espectáculo digno de transitar. Sin embargo, más allá de las ansias por conocer nuevas geografías, Río se convirtió para Greca en un "estereotipo", en una "tarjeta postal". Su gusto por viajar transitando los espacios propios de una geografía cultural, por fuera de las atracciones propiamente turísticas, se vio frustrada por el uso del automóvil. Al no poder recorrerla a pie o en transportes públicos, la impresión que deja en su retina y en su sensibilidad está truncada:

Tengo de Río una impresión un tanto incompleta. Por haberla recorrido siempre en automóvil, merced a la gentileza de mis amigos brasileños, no pude 'ver' la ciudad. Según mi incorregible manera de viajar, a las ciudades, para verlas, se necesita hacerlo andando sobre los pies o, cuando más, en los vehículos del pueblo, tranvías y ómnibus que se detienen en todas las esquinas, y esto, sin cicerones ni apremios de tiempo. El automóvil debe emplearse excepcionalmente para las largas distancias. Solo así pueden sorprenderse aspectos típicos, notas de colorido local y episodios que pocas veces captan los turistas que se sirven de la agencia Coock. Desde la cumbre del Corcovado, de un aeroplano o de la vagoneta del alambre-carril del Pan de Azúcar, no se ve la ciudad. Se mira una preciosa tarjeta postal (Greca, 1950a, p. 22).

Río es, para nuestro viajero, cosmópolis latinoamericana, artefacto de pasajes e intercambio, capital con inmigrantes y aves de paso: "Río de Janeiro, como París, Buenos Aires y Nueva York, como todas las grandes capitales, es una ciudad de población flotante e importada, llena de turistas, de provincianos y de extranjeros" (Greca, 1950a, p. 28). Río es la urbe del turista y paralelamente, la ciudad funcional del urbanismo: simultáneamente concentra una y varias ciudades en un mismo relato de viajes, cada una con su estatuto semiótico y su potencia. Por eso, Greca expresa que no es exclusivamente una capital política, ni un centro turístico, industrial o de cultura. Tampoco es plutocrática o proletaria. Río es todo eso junto: "una pequeña síntesis del 
mundo" (Greca, 1950a, p. 23). En cambio, San Pablo es caracterizada por el sanjavierino como una empresa y Bahía, como un estupendo museo.

\section{Catedrales y rascacielos}

En Bahía, por su parte, Greca se siente sorprendido por su doble aspecto de ciudad alta y baja, comunicada por ascensores. También lo cautiva su colorido, sus numerosas y artísticas iglesias. En cambio, en el centro-sud de la llamada orla oceánica, sobre una elevada meseta, a cien kilómetros de la costa, San Pablo es presentada como "la Nueva York de Sud América" (Greca, 1950a, p. 4). En perpetua fiebre, con el pulso acelerado, sus rascacielos suben y suben, en permanente competencia, ganándoles en altura a los de Río y Buenos Aires. Los rascacielos funcionan como un remanso del orden (Gorelik, 2009, p. 35) y de la modernidad y una demostración del poderío de un pueblo: la ecuación que articula civilización, modernización e industria resuena en el texto de Greca para definir a la capital del mundo -Nueva York-por su industrialización desbordante y compararla con San Pablo.

Un conciudadano y amigo de Greca fue quien se ocupó unos años antes de definir a los rascacielos como "la obra de arquitectura más extraordinaria de nuestro tiempo". Nos referimos al arquitecto, ingeniero, urbanista e historiador del arte Ángel Guido (Rosario, 1896-1960), quien por ese entonces (1948-1950) se desempeñaba como rector de la UNL. En efecto, Guido había publicado un texto titulado "Catedrales y rascacielos $6 "$, donde expresaba que el rascacielos implica el triunfo del verticalismo y un reto a las trabas impuestas por la pesadez de los materiales (Guido, 1936, pp. 22- 32). De este modo, se constituye en el índice certero revelador de la prosperidad económica. Sin prestar homenaje a la escala humana, el rascacielos -que nació históricamente bajo el espíritu de su majestad la renta y bajo los impulsos de la técnica y la máquina- "se proyecta en los bancos, en los directorios de poderosísimas entidades financieras, en las gerencias de los trusts". Greca (1950a, p. 11) coincide con esta perspectiva y expresa: "Se ha dicho que los rascacielos más altos de Nueva York no se han construido en virtud de necesidades económicas sino por espíritu de competencia. Algo de esto ocurre en San Pablo. El Banco del Estado no necesita para funcionar treinta y cinco pisos, más un mirador con otros cuatro... ipero los tiene! Existen edificios que van llegando ahora a los cuarenta y cinco pisos".

Desde rascacielos, ferrocarriles y medios de transporte hasta el suministro de agua potable y los barrios industriales son de su más profundo interés. Dentro de los intereses intelectuales de Greca, el urbanismo funciona como un hilo conductor, un vertebrador. En el fragmento que reproducimos a continuación, describe un barrio de San Pablo, a través

\footnotetext{
6 Este opúsculo editado por el Colegio Libre de Estudios Superiores de Buenos Aires surge a raíz de unas conferencias cuyo título originario es "Génesis, apogeo y crisis del rascacielo". Guido propone leer este breve texto en vinculación con otros dos que todavía no había escrito: El Alejaidinho (que publica posteriormente en 1938 y que versa sobre el gran escultor leproso del siglo XVIII en el Brasil) y Diego Rivera (texto que nunca llegó a publicarse, más aún creemos que nunca se escribió). Para Guido (1936), "la obra de arte es fenómeno vivo, al cual solo cabe descubrirlo, merced a una actitud sintonizante, por calurosa simpatía emocional, es decir, mediante una suerte de endopatía o proyección sentimental".
} 
Antequera. Con los ojos puestos en ese continente con forma de arpa: arquetipos brasileños, búsqueda escrituraria...

del procedimiento retórico de la enumeración y deja traslucir su recurrente interés por pensar y describir la ciudad ordenada: "El Barrio Industrial, trazado bajo los lineamientos del más depurado urbanismo, lo contiene todo: parques, avenidas, barrio obrero, centro cívico, clubes, restorantes y hasta una torre del reloj. Lo circundan los canales de los ríos Tieté, Pinheiros y Jaguaré. Hay frigoríficos, estación de ferrocarril, usina, centros de investigaciones tecnológicas, escuelas, estación sanitaria. Junto al Barrio Industrial se levantará la Ciudad Universitaria" (Greca, 1950a, pp. 18-19).

Por otra parte, con respecto a Bahía, Greca recurre a una suerte de paneo cinematográfico y expone:

Pero no podría dar término a esta crónica sin intentar siquiera una pincelada evocadora de Bahía, en contradicción con lo que acabo de expresar respecto de las descripciones de ciudades, que remito a la fotografía y al cinematógrafo.

Bahía es una fiesta de color. Las calles se van desarrollando ante las miradas del viajero en una sucesión de casas de frentes lisos, pero de intensos colores. Se ven amarillos, rojos, verdes, azules, rosas pálidos, lilas... De vez en cuando, aparece una blanca y reluciente fachada recubierta de mayólicas rameadas de finos arabescos. Las puertas y ventanas, también de vivos tonos, hacen contraste con las paredes. En las avenidas residenciales se ven chalets que emergen cual una llamarada entre el esmeralda de la fronda. El 'confitado' Luis XV, con sus florones de argamasa, no llegó a Bahía, pero ya se ve el moderno funcional, con sus frentes blancos y lisos en algunos edificios públicos: escuelas y hospitales. En los alrededores, la carmínea tierra del Brasil abre anchas heridas entre el verdor de los campos. Todo es alegre, limpio, acogedor. Las cabañas rodeadas de huertas, nos hacen pensar en gentes felices, libres de preocupaciones (Greca, 1950a, pp. 23-24).

El modo de aproximación a los artefactos urbanos pasa por la visualidad, cuestión que ya fue transitada por Greca en otros registros escriturarios: nos referimos claro está a La torre. Quizás esto pueda pensarse como una marca tributaria de su labor como cineasta. Utiliza imágenes visuales, alusiones cromáticas, impresiones, instantáneas que plásticamente son descriptas. Greca se detiene a ensalzar con esmero el carácter policromático de Bahía, ciudad que define como "una fiesta del color". Con el objetivo de detallar aquello que ve, la profusión de tonalidades deviene en imágenes vívidas, intensas, especialmente al describir pródigamente fachadas de casas. Muy a menudo, estimula lo que podríamos llamar, a falta de mejor rótulo, la imaginación colorística del lector (refiriéndose a "carmínea tierra" o "la esmeralda de las frondas"). Nos parece que la fina percepción cromática de Greca es un dato interesante ya que los detalles en los cuales repara definen el ojo que avizora.

7 Del mismo modo que define a la ciudad de Lima en La torre. 
Aunque no solo tiene en cuenta los colores de las fachadas de las casas sino también los ornamentos de las mismas: hace alusión a las mayólicas, los florones de argamasa, por citar solamente algunos, que contrastan con los frentes blancos y lisos de los edificios públicos (por ejemplo, escuelas y hospitales). Igualmente, en su paso por esta ciudad repara en el arte de sus iglesias, la magnificencia de sus riquezas, sus altares, cuestión que contribuye a cimentar la credibilidad del testimonio avalada por la experiencia del protagonista (Greca, 1950a, p. 24):

El Salvador, verdadero nombre de Bahía, es la ciudad de las iglesias. Llegó a decirse que eran tantas como los días del año, pero es sólo una leyenda [...], diremos que no es el número lo que hay que admirar sino el arte insuperable de su estilo arquitectónico, la magnificencia de sus altares, las riquezas que atesoran y las leyendas que las prestigian.

No cometeré la ingenuidad de engolfarme en una descripción de lo que ya se ha hecho en gruesos volúmenes por eximios expertos, pero diré que es difícil olvidar a San Francisco, sinfonía en verde y oro, a la Catedral y a las capillas de la Orden Tercera y de la Santa Casa de la Misericordia. Pero no son solo los recintos destinados a los fieles; hay que visitar las sacristías, los refectorios, las salas nobles de las congregaciones y los claustros para ver primorosas obras de talla, magníficos artesonados, mayólicas, finos herrajes de plata y hierro, óleos y frescos de las mejores escuelas. El viajero puede emplear días y días sin que llegue a saciarse.

El arte de las iglesias bahianas, vistas en su completud, es decir, incluyendo los claustros de las congregaciones y los sitios más resguardados al público en general, forja en el viajero una experiencia difícil de olvidar, una huella mnémica indeleble. En consecuencia, la ciudad -y los templos son una parte insoslayable, más aún en una localidad como Bahía- deviene un territorio abierto a la exploración por el desplazamiento dinámico de la visualidad.

Como vemos, dos elementos propios del género son resignificados en su escritura autobiográfica: por una parte, entendemos que la primacía de la descripción en clave topográfica, es decir, la descripción de lugares es una de las claves que debemos destacar. Por otra parte, la aproximación a los objetos se produce desde la visualidad. De alguna manera, podríamos esbozar que se cumple aquello que Adrián Gorelik (2004) señala en estos términos: "la ciudad y sus representaciones se construyen mutuamente".

\section{Urbanismo y derecho municipal, las credenciales del sanjavierino en Brasil}

Llegados a este punto, podríamos preguntarnos por qué Greca fue convocado para dictar conferencias en Brasil. La respuesta tiene un nombre: Rafael Bielsa ${ }^{8}$ (18891956), el jurista más destacado de Rosario a lo largo de la historia y quizás el más

.8 Los especialistas lo comparan con Vélez Sarsfield y destacan su defensa del bien común así como su rigurosidad en el estudio del derecho. 
Antequera. Con los ojos puestos en ese continente con forma de arpa: arquetipos brasileños, búsqueda escrituraria...

prolífero del siglo XX a nivel nacional. En efecto, a instancias del santafesino Bielsa, fundador del Derecho Administrativo en la Argentina y en buena parte de América, Greca es convidado por la Ordem dos Advogados do Brasil, una organización profesional muy importante. En carácter de conferencista estrella, Greca fue recomendado por Bielsa para intercambiar ideas sobre la doctrina del Movimiento Municipalista Interamericano. En las fotografías que materializan esos encuentros, se lo puede distinguir como un orador vehemente (Figura 4), también en reuniones distendidas en Bahía junto a algunos personajes de la intelectualidad paulista, como Ives Orlando Tito de Oliveira en casa de Álvaro Clemente (Figura 5), o durante una entrevista con el gobernador del estado de San Salvador de Bahía, el Dr. Mangabeira (Figura 6). Cabe destacar que en este viaje fue declarado huésped de honor de la ciudad de San Pablo.

En este sentido, coincidimos con Aguilar y Siskind (2002, p. 371) en que "la construcción del escenario en el que se desplegará la performance del viajero cultural implica la participación de varios factores: por un lado, la oferta económica para seducirlo y la solidez material de las instituciones que organizan estas visitas y las difunden. Por otro lado, en una dimensión simbólica, el espacio en el que la palabra del viajero adquiere valor y en el que la interpelación respecto de la identidad se vuelve productiva". Nada sabemos si a Greca le pagaron honorarios por las conferencias dictadas en San Pablo, Bahía y Río de Janeiro (y que luego serán inscriptas en Una nueva capital); aunque sí podemos reconstruir que tanto acudir en representación de la UNL con el espaldarazo de Bielsa, como disertar frente a los colegas brasileños de la Ordem dos Advogados do Brasil entrañaba una experiencia que acrecentaba y consolidaba su prestigio profesional. Además, como si escribir exigiera viajar y viceversa, la experiencia traslaticia se constituyó en un viaje de trabajo, cuyas impresiones fueron inscriptas a posteriori.

El núcleo de estas conferencias - género privilegiado de esta escena de interpelación (Aguilar y Siskind, 2002, p. 372) - era debatir en torno al proyecto del traslado de la futura capital brasileña y la creación de Brasilia, tema de sumo interés para los intelectuales latinoamericanos afines a estas problemáticas entre los que Greca tenía un lugar destacado. Resulta digno de mencionar, además, el respeto que suscitaba entre sus colegas ${ }^{9}$ : por ejemplo, el importante urbanista Ives Orlando Tito de Oliveira (1953), quien recibió a Greca en San Pablo y con quien sostuvo productivos diálogos científicos, expresaba:

Duas figuras continentais merecem $[\ldots]$ serem citadas como representantes máximos do continente emconhecimento, autoridades e trabalhos realizados: os professores Alcides Greca, da Argentina e Adriano Carmona Romay, de Cuba. Dois exponentes magníficos, dois mestres consagrados, dois idealistas puros e dois nomes dignos de nosso respeito e admiracáo profunda. Nossas simples, modestas e resumidas aulas tivieram como esteios entre outros as linóes desses dois professores que honram a consciência des Américas.

\footnotetext{
9 También en una obra contemporánea de suma importancia para los estudios urbanísticos se ponderan positivamente los aportes del sanjavierino: nos referimos a Fuentes para el estudio de José Martí en materia municipal del cubano Adriano Carmona Romay (1953).
} 
Figura 4. Alcides Greca ofreciendo una conferencia en la Ordem dos Advogados do Brasil (Bahía)

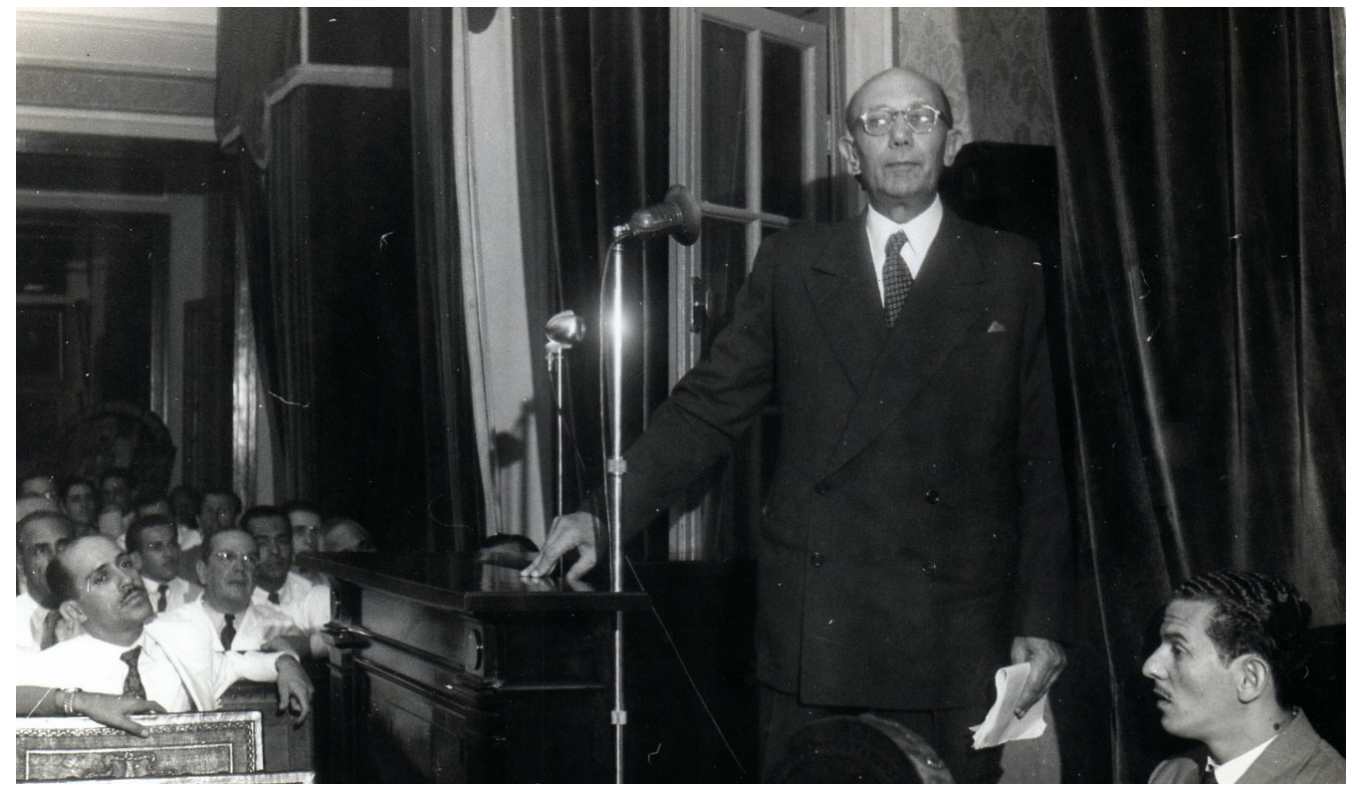

Fuente: Fondo documental Alcides Greca.

Figura 5. De izquierda a derecha. Milton Santos, Ives de Oliveira, Alcides Greca y Álvaro Clemente. En Bahía, en casa de Clemente

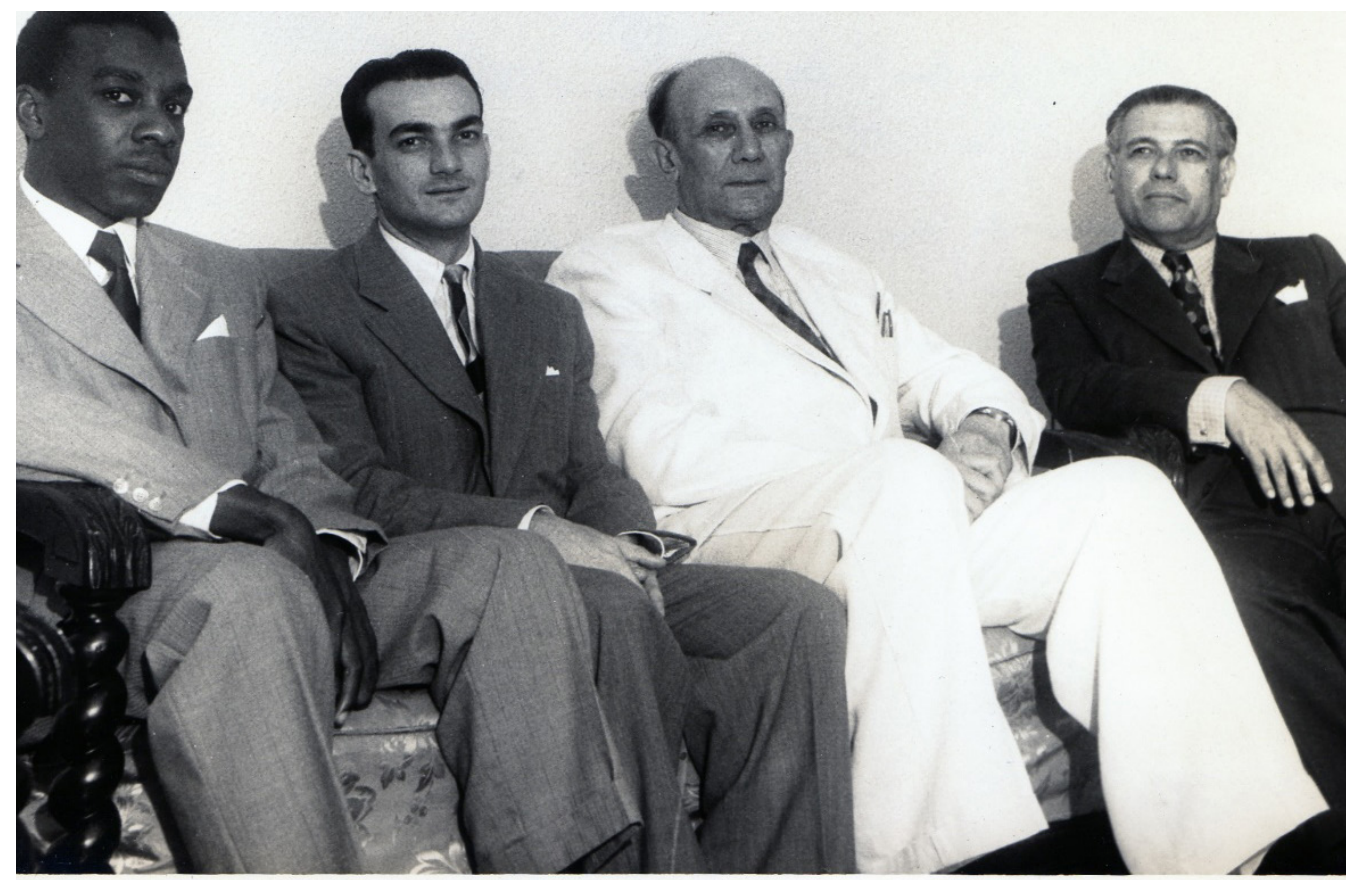

Fuente: gentileza Familia Greca (Fondo documental Alcides Greca). 
Antequera. Con los ojos puestos en ese continente con forma de arpa: arquetipos brasileños, búsqueda escrituraria...

Figura 6. Alcides Greca junto al Dr. Mangabeira en San Salvador de Bahía. En segundo plano, Ives de Oliveira

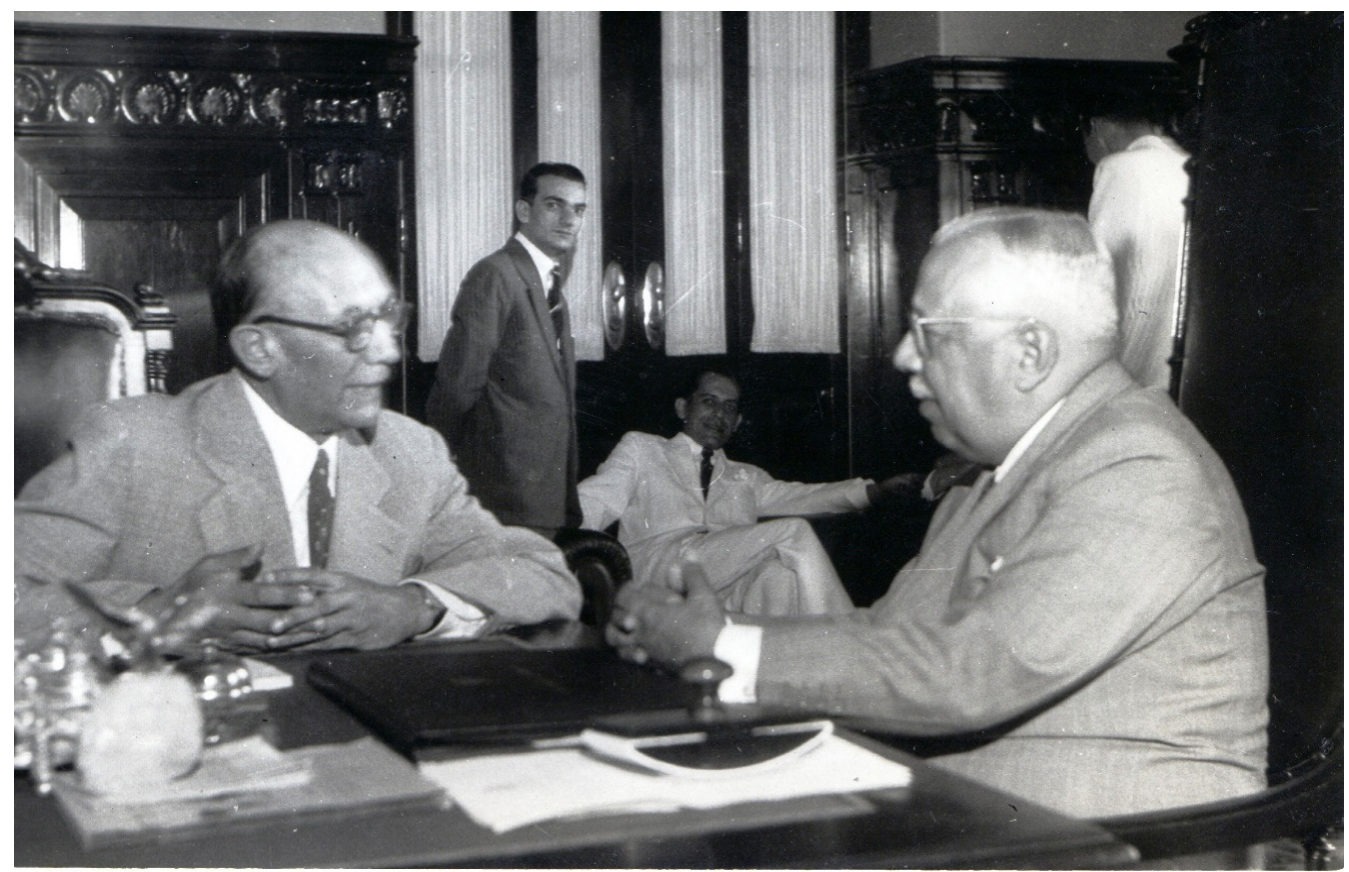

Fuente: gentileza Familia Greca (Fondo documental Alcides Greca).

Antonio Delorenzo Neto, también otro destacado intelectual brasileño dentro del planeamiento urbanístico-regional, subrayaba que los programas de Derecho Municipal de las cátedras de Greca y Carmona Romay son los dos más famosos del continente ${ }^{10}$ (Delorenzo Neto en Carmona Romay, 1953). Greca tenía la voluntad constructiva de nuevas coordenadas en este espacio del saber, que se estaba robusteciendo, y entendía que la emergencia del traslado de la capital brasileña se constituía en un epifenómeno insoslayable para alzar su voz. Bahianos, en este sentido, forma parte de este contexto y no omite - aunque en los intersticios - datos relativos a ese particular momento histórico para el urbanismo latinoamericano. Sin embargo, es en Una nueva capital donde Greca deja constancia de sus pareceres en clave de jurisconsulto.

En esas conferencias, midió sus conocimientos frente a auditorios de especialistas en las dos ramas del saber: el derecho municipal ${ }^{11}$ entendido como

\footnotetext{
${ }^{10}$ Estas palabras son de Antonio Delorenzo Neto (1952, p. 70) en su texto "A Importancia da Técnica Tributaria e do Ornamento na Planificado Municipal” y están recogidas por Carmona Romay (1953). "Considerando el desarrollo de los Programas de Derecho Municipal en las cátedras de Alcides Greca y Carmona Romay, en Argentina y Cuba, respectivamente, para citar las dos más famosas del Continente" (Traducción nuestra)

${ }^{11}$ El derecho municipal, puesto al servicio de la ciencia del urbanismo, bajo cuyas directivas se encauza, se aparta, también, de las fuentes comunes a las otras ramas de las ciencias jurídicas, donde la costumbre y la tradición juegan un papel preponderante. Constituye, con el derecho administrativo, del que es en realidad, una parte especializada, un 'derecho vivo', que actualiza el porvenir y cuyo vigoroso impulso
} 
"el conjunto de principios y normas de jurisprudencia referentes a la integración, organización y funcionamiento de los gobiernos locales" (Carmona Romay, 1950, p. 19) y el urbanismo. Tal vez nos convenga recordar la lección de Greca en este último campo disciplinar, ya que lo concebía como uno de los capítulos principales de la historia de la cultura y como ciencia que concentra en sí una multiplicidad de disciplinas: "en el estudio de los problemas urbanos intervienen el arquitecto, el ingeniero, el sociólogo, el jurista, el historiador, el economista, el geógrafo, el artista, el psicólogo y vienen a ser urbanistas todos", apunta Greca (Greca en Boasso, 2011, pp. 99-101). Esta mirada multidisciplinaria, amplia e innovadora, que no ejercía la primacía por cierto entre sus pares, se postulaba como una alternativa a las perspectivas más reduccionistas, ligadas estrictamente a la ingeniería y a la arquitectura ${ }^{12}$. Es así como en un texto de 1939, sistematizará sus aportes en estos términos:

[el urbanismo] no debe ser considerado como una ciencia autónoma, específica, que se concreta en una determinada disciplina. Consiste, más bien -decíamos- en una amplia cultura, que toma sus elementos de la ingeniería, el derecho, la medicina, la economía política, la sociología, y el arte. No se nos oculta que algunos autores pretenden circunscribirla al campo de la ingeniería y de la arquitectura, refiriéndola a la construcción material de las ciudades, pero, no pocos, opinan ya que el verdadero urbanismo debe recurrir a todas las ciencias que son aplicables a la distribución y buen gobierno de la población humana (Greca, 1939, p. 19).

Greca bregó por estos postulados en una intensa y sostenida labor desde los claustros universitarios. Además de ejercer la docencia en los espacios curriculares de Derecho Administrativo y Derecho Municipal Comparado, detentó varios cargos $\mathrm{y}$ responsabilidades institucionales ${ }^{13}$. Conviene reparar que las cuestiones relativas al urbanismo comenzaron a tomar fuerza en la UNL, a merced de tres abogados, figuras

llevará a la sociedad a realizaciones hoy imposibles de prever" (Greca, 1939, 10). Para ahondar en torno al régimen jurídico municipal en la concepción de Greca sugerimos consultar el cap. 3 de la tesis de Maestría (FLACSO) de M. Ternavasio (1991) titulada: "Municipio y política: un vínculo conflictivo". Disponible en: http://historiapolitica.com/datos/biblioteca/ternavasio.pdf

${ }_{12}$ Para mayores datos sobre la vinculación de Greca y el urbanismo, ver Levrand, Norma Elizabeth: "Contenidos urbanísticos en la carrera de abogacía de la Universidad Nacional del Litoral (Argentina, 1920-1948), Hist. Educ. (Online) Porto Alegre v. 21 n. 51 Jan./abr., 2017; Hernández, Antonio María: Derecho municipal: parte general, UNAM, México, 2003, y Mazza, Carlos: "El pensamiento urbanístico y territorial de Alcides Greca" Disponible en: https://rephip.unr.edu.ar/bitstream/handle/2133/7001/ Carlos\%20Mazza.pdf?sequence $=3 \&$ isAllowed $=y$

${ }^{13}$ Según consta en su legajo académico ${ }^{\circ} 748$ de la Facultad de Ciencias Jurídicas y Sociales de la UNL, fue Director del Instituto de Ciencias Jurídicas, Consejero Directivo, Consejero Superior, Director de la revista de dicha institución, representante de esa casa de altos estudios en diversos eventos científicos como, por ejemplo, el Congreso Panamericano de la Vivienda Popular (1939). A partir del año 1948 renuncia a esta facultad y se dedica por entero a la Facultad de Ciencias Económicas, cuya sede estaba en la ciudad de Rosario. El motivo radica en que la Facultad de Ciencias Jurídicas tenía sede en la ciudad de Santa Fe. 
Antequera. Con los ojos puestos en ese continente con forma de arpa: arquetipos brasileños, búsqueda escrituraria...

de fuste en la vida universitaria: nos referimos a Rafael Bielsa, José Lo Valvo (Rosario, 1895- Rosario, 1971) -futuro intendente de Rosario y decano de la Facultad de Ciencias Jurídicas y Sociales de la UNL durante el período 1932-1936- y el intelectual que nos convoca. Estos tres jurisconsultos coincidían en la importancia de impartir, desde la cátedra universitaria, conocimientos relativos al urbanismo para la formación académica del abogado. La implicancia es algo más que una estrategia argumentativa, es la marca retórica de un núcleo de sólidas convicciones que resultaban innovadoras para el momento de su enunciación. Más aun teniendo en cuenta que Alcides desarrollaba estas cuestiones articulándolas dentro de la cátedra de Derecho Municipal (Fac. de Ciencias Jurídicas y Sociales, UNL), del que fuera titular por más de dos décadas.

Estas prácticas en torno a los conocimientos urbanísticos devienen ciertamente novedosas ya que conjugan diversos planos de la función social de la universidad. De hecho, sus prácticas transversalizan actores, funciones y saberes -en el sentido que aportábamos en Antequera et al (2015)—, relacionando la docencia, la investigación, la gestión y la divulgación del conocimiento en clave de extensión universitaria. En otros términos, entendemos que aunaba en sus propias prácticas universitarias estas funciones, en una disciplina, que ciertamente como apuntábamos más arriba estaba fundando, en el sentido más estricto del término. Al intentar articular estas funciones incidía en la implantación de la disciplina en la universidad, contribuyendo a formar a los futuros profesionales del Derecho. El campo de batalla de la disciplina, batalla por consolidar las ideas del urbanismo en ciernes y batalla por la legitimación del espacio de la disciplina, como vemos, también se libraba en el currículum universitario.

\section{Una nueva capital para la Nación Argentina}

Ahora bien, para calibrar la importancia de la obra jurídica de Greca, razón por la cual fue invitado a Brasil, recogemos unas palabras que Bielsa -su referente y compañero de cátedra- profirió en el prólogo a un texto póstumo del sanjavierino, Régimen legal de la propiedad (1956). Bielsa (1956, p. VIII) caracteriza la obra jurídica de Greca en estos términos: "La principal obra de este autor es Derecho y ciencia de la administración municipal, notable resumen metódico de su enseñanza en la Facultad de Derecho de Santa Fe, durante un cuarto de siglo. Ha escrito, además, importantes monografías sobre urbanismo y cuestiones administrativas. Precisamente el libro sobre la vivienda es de esa índole, aunque no se limite a ese problema, en el cual el derecho privado tiene un área considerable". En el momento de llevar a cabo el viaje por Brasil, Greca ya había publicado una decena de volúmenes abarcando diversos géneros literarios (poesía, narrativa, relato de viajes, ensayo ${ }^{14}$ ). Asimismo, sobre jurisprudencia

\footnotetext{
${ }^{14}$ A continuación, citamos la nómina de sus obras literarias: Palabras de pelea (1909), Sinfonía del cielo (1910) y Lágrimas negras (1910), Laureles del pantano (1915), Viento norte (1927), La torre de los ingleses (1929), Cuentos del comité (1931), Tras los alambrados de Martín García (1934), La pampa gringa (1936), En torno al hombre (1941), Bahianos y bandeirantes (1950). Con respecto a sus obras jurídicas, la cronología de publicación es la siguiente: Derecho y ciencia de la administración municipal (1937), Problemas de urbanismo en la República Argentina (1939), Una nueva capital para la Nación Argentina (1950), Régimen legal de la construcción (1956).
} 
ya había editado Derecho y ciencia, al que Bielsa hace referencia, texto que, al decir de los especialistas, todavía no ha perdido vigencia. De igual modo, ya había publicado Problemas de urbanismo en la República Argentina (1939) y tantas otras obras más.

Escrito durante 1949, Una nueva capital salió a la luz un año después. En él se puede leer: "Una reciente visita al Brasil nos ha permitido observar de cerca la vigorosa campaña emprendida en este país por eminentes publicistas y hombres de estado con el fin de lograr el reacomodamiento de las instituciones a sus graves y permanentes problemas nacionales". Para más adelante, agregar: "El más fundamental consiste en obtener un cierto equilibrio económico, político, demográfico y social entre las distintas entidades territoriales que constituyen esta inmensa y rica nación (Greca, 1950b, p. VII).

En esta obra ${ }^{15}$, Greca ensaya una solución al problema que, perentorio de resolver, lo desvela: el dislocamiento de la nación ${ }^{16}$. Para evitar la dispar distribución poblacional en el territorio argentino, resulta necesario entonces la fundación de una nueva ciudad capital en el interior de las provincias (1950b, p. VI), en consonancia con los debates que se estaban librando en Brasil. Las propuestas de Greca residen en restaurar la argentinidad por medio del federalismo y la revitalización del régimen municipal. La multiplicidad de asuntos tratados engarza cuestiones de índole económica, soluciones con tintes políticos y un repaso histórico de las causas para que se haya llegado a tales grados de centralismo en Argentina. Es así como revisita el amplio espectro de intelectuales que incluye a D. F. Sarmiento, R. Rojas y E. Martínez Estrada, por citar solo algunos.

Junto a estos tópicos, también se pueden relevar sus conspicuas hipótesis en torno al cosmopolitismo y a lo que él elige denominar "la solución brasileña" frente a estos problemas. Su tesitura sobre el mal que aquejaba a la Argentina puede resumirse en el centralismo de Buenos Aires que ahoga a las provincias. Debido al desequilibrio económico y demográfico que vive la Argentina en claro desmedro de los habitantes "del Interior", se siente interpelado por su reciente visita a Brasil, ya que frente a un problema semejante que comparten ambos países -el ingente centralismo- Brasil halla una novedosa respuesta.

La causa madre de esta problemática, epitomiza Greca, es la imprevisión que permitió que miles de inmigrantes no traspasen las fronteras de Buenos Aires. De manera concomitante, si la meta puede resumirse en las elocuentes frases "restaurar la argentinidad" y "evitar el dislocamiento de la Nación”, la solución pasa por "fundar una

\footnotetext{
${ }^{15}$ Greca sostiene que en realidad debió titularse: "La Restauración del Interior”. Los capítulos son cinco: 1) "Desequilibrio económico-político"; 2) "Una capital indefensa y turbulenta"; 3 ) "El problema y algunos publicistas" donde pasa revista a las conceptualizaciones que hicieron diversos intelectuales argentinos, desde Alejandro Bunge, Juan Álvarez y Bernardo Canal Feijóo hasta Ezequiel Martínez Estrada; 4) "La solución brasileña" y 5) "Solución argentina". Sin embargo, consideramos que el estudio de Una nueva capital... resulta de utilidad para nuestra investigación porque echa luz sobre otros aspectos de Greca, en su rol como intelectual comprometido con su tiempo: quedará para nuevos trabajos estudiar las vinculaciones con el pensamiento de D. F. Sarmiento y de J. Álvarez, E. Martínez Estrada y R. Rojas

${ }^{16}$ Podríamos decir que Greca no busca la nación como forma sino como proceso de metamorfosis (Antelo, 1998), como aquello que debe cambiar y refundarse.
} 
Antequera. Con los ojos puestos en ese continente con forma de arpa: arquetipos brasileños, búsqueda escrituraria...

Ciudad-Capital en el interior del territorio" (Greca, 1950b, VI) ${ }^{17}$. De este modo, aviva los resortes de un federalismo afincado en el municipalismo. Es así que, si pensamos específicamente en la trayectoria de Greca, el urbanismo se propone en una ambiciosa clave, que implica descentralización, equilibrio regional y municipalismo (Cfr. Greca, 1950b: VIII) o, en otros términos, un renovado federalismo que habría de concretarse, entre otros puntos, en la erección de una nueva capital.

Este es en resumidas cuentas el contenido de las intervenciones: la ciudad ordenada del urbanismo, el federalismo y la revitalización del régimen municipal son las temáticas sobre las que disertó Greca y sobre las que gravitó con mayor solvencia académica en su itinerario intelectual.

\section{Anfitriones}

Llegados a este punto, conviene entonces pasar revista a quienes fueron sus interlocutores válidos en tierras brasileñas. A propósito de las vinculaciones sociales, en sus otros relatos de viaje se puede apreciar que Greca traba relaciones -sin hacer distinciones- con personas de todas las clases sociales: en definitiva, el espectro de sus lazos sociales es amplísimo. No obstante, en Bahianos se trasluce una inclinación por estrechar lazos con intelectuales, magistrados, industriales, urbanistas, en fin, hombres de la cultura y la política de su tiempo. Por eso, resuena el siguiente elenco, que ya describiremos: Francisco Prestes Maia, M. Teixiera de Freitas, Rafael Xavier, Ives Orlando Tito de Oliveira, Plinio Branco, Aliomar Baleeiro, entre otros. Obviamente, esta tendencia está fundada en que Greca viaja en calidad de representante de una institución de estudios superiores. Pero, además, teniendo en cuenta que ya había consolidado un prestigio profesional basado en sus intervenciones artísticas y académicas, es buscado como un referente entre sus pares.

El andariego sanjavierino viaja infatigablemente; a la sazón, casi no hay lugar para el descanso: sus anfitriones fueron pródigos en atenciones y detalles de camaradería. El reconocido urbanista, y ex prefecto de San Pablo $^{18}$, Francisco Prestes Maia (18961965) es su cicerone en dicha ciudad. Dos décadas antes, en 1930, este ingeniero civil y arquitecto había presentado el proyecto de un plan general para esta ciudad, basado en avenidas radiales y perimetrales, conocido como el Plan de Avenidas, documento clave del urbanismo brasileño porque es la primera vez que se piensa la ciudad como un todo ordenado. Por este plan, recibió un premio en el $4^{\circ}$ Congreso Panamericano de Arquitectos celebrado en Río de Janeiro (1930). Las ciudades de Recife, Campos do Jordão, Santos y Campinas ${ }^{19}$ también fueron objeto de sus intereses urbanísticos. Por estas temáticas de interés que compartían con Greca, resulta dable afirmar que si no se conocían de reuniones y simposios previos, al menos, por intermedio de sus escritos

\footnotetext{
${ }^{17}$ Sugiere denominar esta nueva ciudad capital con algún derivado de San Martín.

${ }^{18}$ En los períodos 1938-1945 y 1961-1965.

${ }^{19}$ Entre sus publicaciones destacamos: Estudo de um plano de avenidas para a cidade de São Paulo (1930); São Paulo, metrópole do século XX (1942); O plano urbanístico da cidade de São Paulo (1945); Plano regional de Santos (1950).
} 
ya que Greca interactuaba con los postulados de Prestes Maia y dominaba los de otros urbanistas brasileños como M. Teixiera de Freitas, Rafael Xavier e Ives Orlando Tito de Oliveira, ya que venía trabajando en estas premisas y observando el proceso con Brasilia, como se puede vislumbrar en las enjundiosas páginas que le dedica a cada uno en Una nueva capital.

En Bahianos (Greca, 1950a, p. 19) relata que el urbanista Prestes Maia ofició como guía: "Con velocidad cinematográfica, pero viéndolo todo, sin perder detalle, recorremos fábricas y talleres". Ambos visitaron asimismo el taller del premiado escultor Victor Brecheret ${ }^{20}$, importante figura del arte brasileño, quien estaba trabajando, desde la década del 20, en un monumento que rememora las famosas marchas de los bandeirantes, titulado "Monumento a las banderas" (inaugurado en 1953) y que luego, con el correr de los años, se convertiría en uno de los símbolos de la ciudad de San Pablo. Greca describe ese monumento en detalle:

En breve será ubicado en uno de los paseos de la ciudad un monumento [...] que rememora las famosas marchas de los bandeirantes. El urbanista Prestes Maia, el genial ex prefecto que transformó a San Pablo, nos lleva al taller donde podemos admirar esta obra estupenda. Se ve una caravana, que ocupará no menos de cincuenta metros de longitud, Abren camino dos arrogantes ginetes (sic), dos mamelucos sin duda en cuyo gesto se percibe la decisión de seguir adelante, de llegar a la meta. Sígueles un grupo a pie, que arrastra penosamente una embarcación. Unos están erguido aún; otros se inclinan ya agonizantes. Se ven indios, mujeres, frailes, jefes y soldados. Es la marcha por los desiertos, las selvas y los pantanales, donde van cayendo los expedicionarios, pero sin que jamás abandone a los sobrevivientes la esperanza y el inquebrantable propósito de no claudicar (Greca, 1950a, pp. 7-8).

En la ciudad mercantil de San Pablo también comparte charlas con otro eximio municipalista, el ingeniero Plinio Branco, redactor de obras jurídicas cuyo foco estaba puesto en los servicios públicos (otro tema de interés para el sanjavierino y que abordó en Problemas de urbanismo...) rivalizando con Meirelles Teixera y Carvalho Pinto, profundos juristas que son a la vez técnicos en finanzas.

Asimismo, Greca se relacionó con políticos locales como los miembros de la Cámara Municipal de Bahía y con estudiantes y docentes universitarios. Los letrados que son nombrados en el relato funcionan como dispendiosos en afabilidad y amabilidad, por ejemplo: "el diputado Aliomar Baleeiro, uno de los más inteligentes y arremetedores del Congreso, y que es, además, profesor de Finanzas, me proveyó de una minuciosa lista de los platos regionales típicos que debía gustar en Bahía" (Greca, 1950a, p.17). Baleeiro

\footnotetext{
${ }^{20}$ Brecheret fue uno de los participantes de la Semana del Arte Moderno en 1922 y ganó múltiples concursos. En 1951 recibió el premio al "Mejor Escultor Nacional" en la primera Bienal de San Pablo
} 
Antequera. Con los ojos puestos en ese continente con forma de arpa: arquetipos brasileños, búsqueda escrituraria...

era representante de Bahía en la Cámara Federal de Diputados. Greca lo define como "campeón del municipalismo en la Constituyente, su nombre es altamente valorado en la opinión pública de todo el país. Es un estudioso y luchador de gran envergadura, que marca rumbos a las nuevas generaciones brasileñas" (Greca 1950b, p. 116). Baleeiro lo lleva a su chacra en el barrio de Cabula donde toman agua de coco. Comparte ratos también con Rafael Xavier (secretario general del Instituto de Geografía y Estadística) y con Teixeira de Freitas (director del Departamento de Estadística de Educación y Salud Pública) y con el Prefecto de la ciudad de San Pablo, Milton Improta.

En calidad de huésped oficial de la ciudad de San Pablo, el Departamento Jurídico de la Municipalidad puso a su disposición un automóvil con chofer. Aunque, como decíamos, era ciertamente una personalidad reconocida en el mundo académico de su tiempo, no deja de sorprenderse frente a diversos detalles de camaradería para con su persona. El estado de ánimo del viajero durante su estancia en tierras brasileñas es óptimo: agasajos, recepciones, banquetes, ágapes se constituyen en otras facetas del viaje de trabajo que incluye las visitas protocolares y sus conferencias sobre municipalismo, aunque también deja tiempo a los paseos distendidos y las recorridas urbanas. Como explican Aguilar y Siskind (2002, p. 373), "los recorridos, los contactos formales e informales, las conferencias, los brindis y las reuniones sociales son los diferentes actos (en el sentido teatral) por los que el viajero debe pasar para lograr sus objetivos". Es así como en esta escena de interpelación se entrecruzan "un cuerpo que atrae las miradas y un discurso que intenta legitimar su propia autoridad, un anfitrión que cede un espacio y un género (la conferencia de ideas) en el que se invierte una expectativa. La confluencia de todos estos elementos le otorga sentido a la palabra del viajero cultural".

Junto a Ives de Oliveira comparte su estadía en San Pablo quedando retratado este encuentro también en las fotografías que forman parte de su archivo familiar (Figura 7). Greca lo describe con esta fuerza de enunciación:

Es una figura señera del nuevo Brasil. Doctrinario completo del Municipalismo, lo estudia en sus múltiples aspectos de ciencia y derecho. El urbanismo, los servicios públicos, el derecho fiscal y las actividades administrativas del gobierno comunal son materia de sus diarias preocupaciones. Director de la 'Revista de Dereito Municipal', que aparece en Salvador (Bahía), ha publicado entre otras obras Doutrinação Municipal y recientemente A revolução municipalista na Constituição Brasileira de 1946. Talentoso y dinámico, su acción y su prédica trascienden los límites de su patria y llegan a todos los centros de alta cultura del continente, donde es altamente valorada su personalidad. En nuestra reciente visita al Brasil tuvimos el honor de suscribir con él los 'postulados del Municipalismo Interamericano' que la Asociación Brasileira dos Municipios ha difundido profusamente en América (Greca, 1950b, p. 115). 
Figura 7. Ives de Oliveira (Izq.), Alcides Greca (centro) y Álvaro Clemente (Der.)

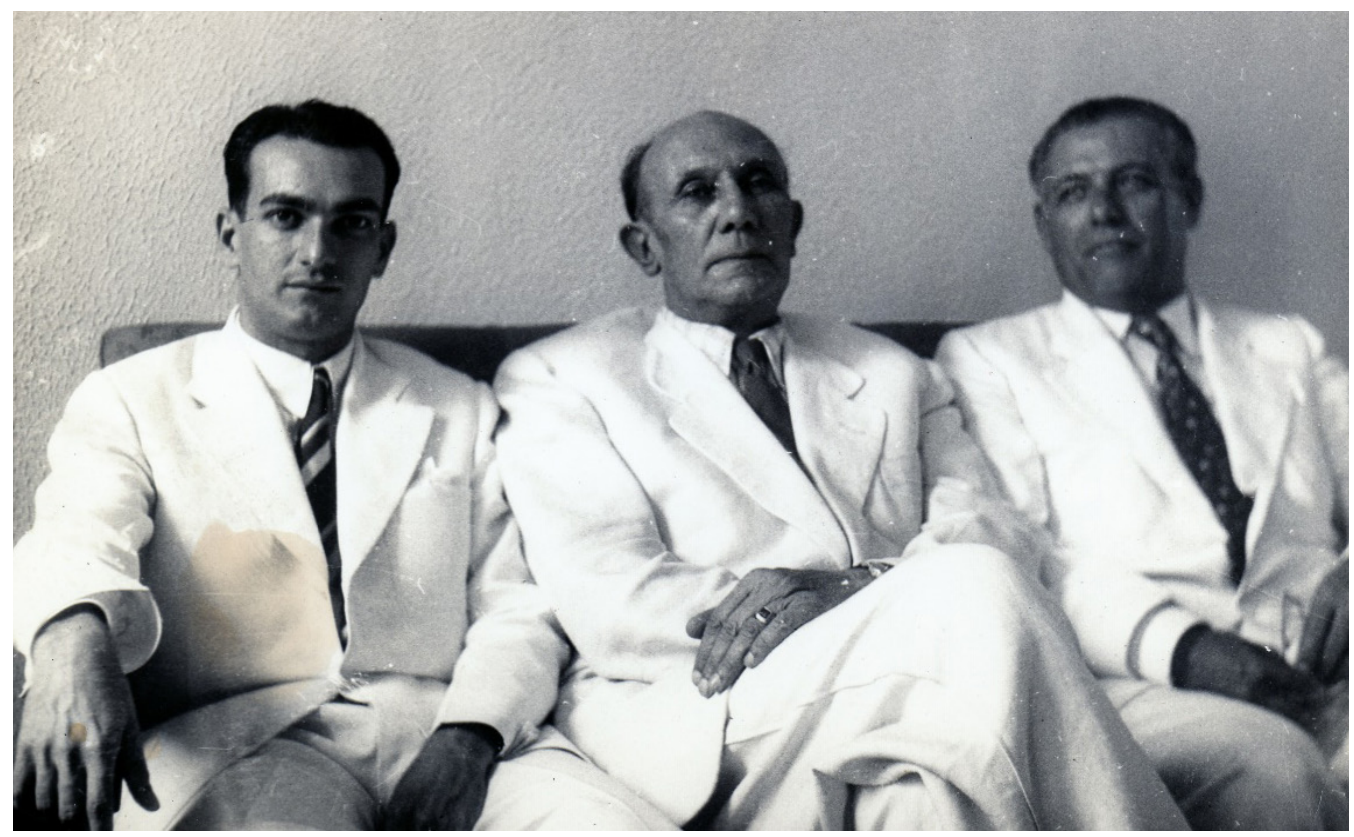

Figura 8. Alcides Greca junto a Ives de Oliveira firmando los postulados del Municipalismo interamericano

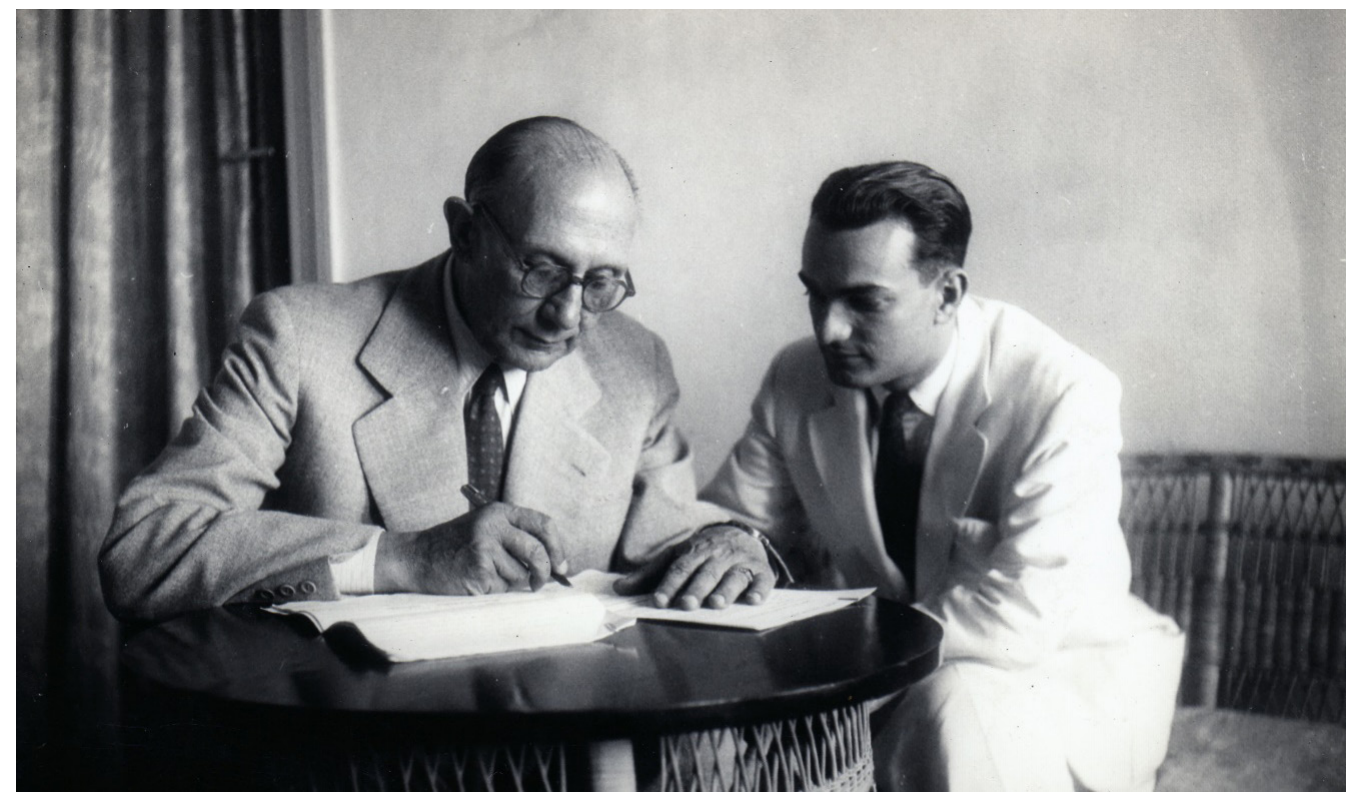

Fuente: gentileza Familia Greca (Fondo documental Alcides Greca) 
Antequera. Con los ojos puestos en ese continente con forma de arpa: arquetipos brasileños, búsqueda escrituraria...

\section{Conclusiones}

Desde joven, el viaje se va volviendo una forma de vivir para Greca: viajar en automóvil o a pie mensurando las calles de las ciudades de ese continente con forma de arpa que es Brasil, pero también viajar de conferencia en conferencia para después viajar entre las ideas defendidas y los ramilletes de experiencias; con el pensamiento y la palabra, es decir, viajar por los libros leídos o escritos.

El Brasil que describe Greca, a fuerza de tamizar los detalles típicamente brasileños, en Bahianos, tiene mucho de la fuerza arrolladora de la visualidad. Greca es un viajero que asume su interés en documentar: los relatos buscan ser documentos de un viaje en primera persona. En estos relatos de viajes se conjugan la presencia de una motivación profesional y la misión institucional, junto a la existencia de un punto concreto de destino considerado como centro del viaje, la ciudad de San Pablo para este fin y la de Bahía para un paseo más distendido. Dicha obra, en tanto autobiografía cincelada y acotada a los meses transcurridos en Brasil, detenta la pretensión de ser fiel a lo relatado y utiliza las estrategias discursivas de la descripción y las comparaciones. La escritura es así la derivación del viaje y también su deriva, la actividad postrera y la labor que documenta. En esa dialéctica entre continente y contenido, entre experiencia y vida, el mundo sensible del viajero adquiere importancia y el relato de viajes se dispone, como una máquina simbólica, a activar la palabra autobiográfica.

Las ciudades recorridas son contrastadas en torno a la modernidad, la ubicación geográfica, la contribución de cada una al país, entre otros ítems, focalizando en elementos de la referencialidad y en la predicación valorativa del espacio. Greca ve en Bahía un modus vivendi afincado en el pasado, frente la proyección al futuro de los paulistas. En las páginas de Bahianos, se presentan y se presuponen el Brasil de la imaginación colorística y la socialización, el de la descripción topográfica de ciudades y el Brasil ejemplar por el urbanismo. Sin embargo, de alguna manera, Greca abordó en Una nueva capital aquello que excluyó en su relato de viajes, la cuestión científica y técnica de la ciudad y las discusiones que eran el telón de fondo de Bahianos. Greca miró a la ciudad como escritor viajero en un caso y como urbanista y jurisconsulto en el otro: uno encarna el racconto de un viaje profesional, y el otro concentra lo vertido en las conferencias que tenían lugar en esos días.

Las visitas a diversos sitios urbanísticos y los contactos con personalidades, en redes de alcance sudamericano, implicaron el despliegue de una intensa actividad y el intercambio intelectual con miembros de universidades, academias, asociaciones profesionales y foros de la sociedad civil, constituyéndolo en un viajero cultural cuya escena de interpelación es la conferencia. Esa edificación del escenario en el que se desplegó la performance del viajero implica la solidez material de las instituciones que organizan estas visitas y las difunden y, asimismo, en una dimensión simbólica, el espacio en el que la palabra del viajero adquiere valor y en el que la interpelación respecto de la identidad se vuelve productiva.

De este modo, podemos concluir que algunos temas van jalonando la obra de Greca y migran a través de diversos registros. Dado que escribir -ya fueran novelas, 
relatos de viajes, libros de urbanismo o artículos-era para Greca una forma de intervenir y alzar su voz frente a aquello que lo interpelaba, observamos también que los vínculos con los temas son afrontados desde distintos recortes de saberes. En este sentido, si Una nueva capital encarna el contenido de las conferencias brasileñas, Bahianos recoge las experiencias traslaticias pero en última instancia, es el mismo objeto analizado desde diferentes registros: la ciudad. Por un lado, desde una perspectiva científica, entre la moderna ciencia del urbanismo y el derecho en la primera obra; y por otro, desde el plano de la literatura de viajes, en la segunda de ellas. En esta dirección, podríamos pensarlos como textos complementarios, donde uno dice aquello que el otro omite. Son dos libros que, al intentar una lectura en paralelo, son planteados en clave contrapuntística, estableciendo una filigrana, acometiendo los huecos de un registro para convocar la obliteración y la astucia del deslinde en el otro. Esos diversos registros escriturarios son dos modos de afrontar ese momento histórico concreto y dos registros diferentes de un solo viaje que tuvo lugar en 1948. Al calor de las mismas experiencias viajeras, Greca desarrolla algunas coordenadas en simultáneo, aludiendo al viaje a Brasil, por un lado, desde una mirada de viajero atento a los paisajes urbanos y, por otro, como especialista en urbanismo y derecho municipal que destaca el modo como Brasil resolvió un problema de proyección nacional: la falta de federalismo que afecta también a la Argentina.

El relato de viajes en la primera mitad del siglo XX es entonces el vehículo escriturario para que nuevas experiencias sociales puedan ser traducidas por intermedio de la escritura de Greca. A través de las descripciones de diversas ciudades, Greca intentará una generalización arquetípica que buscará reconocer los rasgos distintivos fundamentalmente de los bahianos y los paulistas. Los relatos de Greca agrupados en Bahianos despliegan un interés bifronte en tanto documentales y literarios, pues exhiben la necesidad ineluctable de mostrar un itinerario en primera persona, es decir, de acometer una cartografía: la propia, la de Greca en clave de su experiencia en un aquí y ahora. En este ensanche del viaje y de la experiencia, se fragua la legitimación conjunta de proyecto y sujeto.

\section{Referencias bibliográficas}

Aguilar, G. y Siskind, M. (2002). Viajeros culturales en la Argentina. E M. T. Gramuglio (Dir. Vol. 6) El imperio realista. N. Jitrik (Dir.) Historia crítica de la literatura argentina. Bs. As.: EMECÉ.

Antelo, R. (1998). Algaravia. Florianópolis: Editora da UFSC.

Antequera, M. F., Chevasco, M., Craparo, R. y Serra, M.F. (2015). “Articulación social y prácticas sociocomunitarias". Rosario: UNR.

Antequera, M. F. (2017). "Lugares, saberes y epifanías: imágenes proyectuales de

Rosario a partir de un texto inédito de la colección documental del escritor Alcides Greca". Historia regional, 37, 25-37.

Antequera, M. F. (2019a). "La construcción del entramado narrador -protagonista textual- autor en la obra del escritor santafesino Alcides Greca (1889-1956)". 
Antequera. Con los ojos puestos en ese continente con forma de arpa: arquetipos brasileños, búsqueda escrituraria...

Humanidades: Revista de la Universidad de Montevideo, (5), 177-212. https:// doi.org/10.25185/5.7

Antequera, M. F. (2019b). "Enlazar lo heterogéneo: consideraciones teóricas en torno a la arqui-textura del relato de viajes". En C. Maíz (coord. gral.); R. Zo, y M. Campoy (Ed.). Trayectorias de saberes entre Argentina y Brasil. Mendoza: EDiFyL UNCUYO, 22-46.

Antequera, M. F. (2020a). Alcides Greca. El viaje de la escritura y la escritura del viaje. Mendoza: EdiFFyL, Universidad Nacional de Cuyo. https://bdigital.uncu.edu.ar/14948

Antequera, M. F. (2020b) “Alcides Greca (1889-1956), un hombre de letras y un hombre de estudio. Apuntes para la construcción de una biografia escrituraria”. Páginas, 12(30).

Aurell, J. (2004) "El texto histórico como relato autobiográfico". III Congreso Internacional Historia a Debate, Santiago de Compostela, 14-18 de julio de 2004.

Bielsa, R. (1956). "Prólogo". En A. Greca: Régimen legal de la construcción. Bs. As.: Víctor de Zavalía.

Boasso, P. (2011). Juristas rosarinos del siglo XX. 1900-1980. Buenos Aires: Dunken. Carmona Romay, A. (1953). Fuentes para el estudio de José Martí en materia municipal. La Habana: Librería Martí.

Demaría, L. (2014). Buenos Aires y las provincias. Rosario: Beatriz Viterbo.

Ette, O. (2004). Los caminos del deseo. Coreografías en la literatura de viajes. Humboldt, 141, 10-14.

Gramuglio, M. T. (1992). "La construcción de la imagen de escritor". En H. Tizón, R. Rabanal y M. T. Gramuglio. La escritura argentina. Santa Fe: Universidad Nacional del Litoral, 37-64.

Greca, A. (1950a). Bahianos y bandeirantes. Ensayo sobre los hombres arquetipos del Brasil actual. Santa Fe: UNL.

Greca, A. (1950b). Una nueva capital para la Nación Argentina. Rosario: Ciencia.

Gorelik, A. (2004). Miradas sobre Buenos Aires. Buenos Aires: Siglo XXI.

Gorelik, A. (2009). "José Luis Romero: el historiador y la ciudad". En José Luis Romero, La ciudad occidental. Las culturas urbanas en Europa y América. Buenos Aires: Siglo XXI, 15-43.

Monteleone, J. (1998). El relato de viajes. De Sarmiento a Umberto Eco. Buenos Aires: El Ateneo.

Novick y Zanzottera (2019) "La emergencia de los arquitectos como investigadores profesionales en estudios urbanos". A\&P Continuidad, 11(6), 60-69.

Plotkin, M. y Neiburg, F. (2004). Intelectuales y expertos. La constitución del conocimiento social en Argentina. Buenos Aires: Paidós.

Rigotti A. M. y Monti, A. (2018). "Profesionales, expertos y vanguardia: la cultura arquitectónica del Cono Sur". Actas Seminario Internacional. Rosario, Argentina: UNR Editora. Disponible en: https://fapyd.unr.edu.ar/wp-content/ uploads/2018/06/Actas-PEV-alta-res.pdf

Rosa, N. (2006). Relatos críticos. Buenos Aires: Santiago Arcos. 
Santa Cruz, I. (1981). "Los Cuentos del Comité de Alcides Greca”. En AAVV. Narrativa argentina del Litoral. Rosario: Cuadernos Aletheia del Grupo de estudios semánticos, 11-47.

Sarlo, B. (2004). El imperio de los sentimientos. Buenos Aires: Norma. 